UNIVERSIDADE DE BRASÍLIA

FACULDADE UNB DE PLANALTINA (FUP)

PROGRAMA DE PÓS-GRADUAÇÃO EM GESTÃO PÚBLICA - PPGP

André Luis Rabelo Cardoso

A qualidade do Gasto Público: O caso dos Institutos Federais de Educação 
André Luis Rabelo Cardoso

\section{A qualidade do Gasto Público: $O$ caso dos Institutos Federais de Educação}

Dissertação apresentada ao Programa de PósGraduação em Gestão Pública como requisito parcial à obtenção do título de Mestre em Gestão Pública pela Universidade de Brasília ï UnB.

Professor Orientador: Prof. Dr. André Nunes

\section{Brasília Ï DF}

2016 
André Luis Rabelo Cardoso

\section{A qualidade do Gasto Público: $O$ caso dos Institutos Federais de Educação}

A Comissão Examinadora, abaixo identificada, aprova o Trabalho de Conclusão do Curso de Especialização em Gestão Pública da Universidade de Brasília do aluno:

\section{André Luis Rabelo Cardoso}

Doutor André Nunes
Professor-Orientador
$\begin{array}{cc}\text { Doutor Alexandre Nascimento de } \\ \text { Almeida } \\ \text { Professor-Examinador } & \text { Doutor Fernando Antônio Ribeiro } \\ & \text { Professor-Examinador }\end{array}$

Brasília- DF, 16 de fevereiro de 2016 
Ao Grande Arquiteto do Universo, À Família, Aos Amigos, A todos aqueles que, direta ou indiretamente, contribuem para o nosso crescimento pessoal durante essa curta caminhada. 


\section{RESUMO}

É inconteste a influência que os gastos públicos possuem sobre o desenvolvimento econômico e social de uma nação. Nesse sentido, destaca-se na literatura que, para que haja maior crescimento econômico do país, há a necessidade de que o governo diminua a quantidade de gastos em custeio, na manutenção da máquina pública, redundando em maior quantidade de recurso destinado a investimento, sem necessidade de aumento da carga tributária ou contração de empréstimos. Em outras palavras, há a necessidade de melhoria da qualidade do gasto público. Assim, esta pesquisa trata-se de investigar possíveis fatores determinantes da qualidade do gasto público. A amostra compôs-se de 55 Institutos Federais de Educação. A medida de desempenho foi definida a partir da taxa de investimento em relação aos gastos totais desses órgãos e foi testada como variável dependente. As variáveis independentes foram distribuídas em seis dimensões: Capital Humano, Capital Social, Características Gerenciais, Motivação e Cultura, Percepção de Desempenho e Características Organizacionais. As inferências foram realizadas a partir da análise dos indicadores individualmente, e em relação ao conjunto geral, mediante o uso do método econométrico de Regressão Múltipla. Os resultados apontam que os gastos em investimento são determinados pelo conceito macroeconômico de gasto produtivo e conceito de desempenho Orçamentário concebidos pelo Gestor, grau de desperdício do campus, horas de capacitação da equipe que trabalha com o orçamento e grau de ingerências Políticas dentro do Campus.

Palavras-chave: Gasto Público; Investimento; Eficiência. 


\begin{abstract}
It is undeniable the influence that public spending have on the economic and social development of a nation. In this sense, it is emphasized in the literature, for greater economic growth, there is need for the government to decrease the amount of funding expenses, maintenance of public administration, resulting in greater amount of resource allocated to investment, without increasing the tax burden or contraction of loans. In other words, there is a need to improve the quality of public spending. Thus, this research is to investigate possible determinants of quality of public spending. The sample was composed of 55 Federal Institutes of Education. The performance measure is defined from the investment rate in relation to total spending of these agencies and has been tested as a dependent variable. The independent variables were divided into six dimensions: Human Capital, Social Capital, Management Characteristics, Motivation and Culture, Performance and Perception Features Organizational. Inferences were made from the analysis of the indicators individually and in relation to the general assembly, by using the econometric method of Multiple Regression. The results indicate that investment expenditures are determined by the macroeconomic concept of productive expenditure and Budget performance concept designed by the Manager, campus waste of degree hours of training team working with the budget and degree of interference policy in the campus.
\end{abstract}

Keywords: Public Spending; Investment; Efficiency. 


\section{LISTA DE FIGURAS}

Figura 1: Evolução das escolas profissionais no Brasil.......................................... 31

Figura 2: Distribuição das unidades da Rede Federal pelo país................................. 31

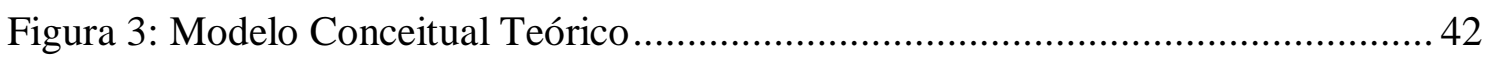

Figura 4: Histogramas do comportamento da tx. de invest. 2012, 2013, 2014 e Média. 51

Figura 5: Gráfico Bloxpot do comportamento do Investimento. ................................54 


\section{LISTA DE TABELAS}

Tabela 1: Caracterização operacional dos indicadores de ñCapital Humanoò. 44

Tabela 2: Caracterização operacional dos indicadores de ñCapital Socialò. 45

Tabela 3: Caracterização operacional dos indicadores de ñCaracterísticas Gerenciaisò. 46

Tabela 4: Caracterização operacional dos indicadores de ñMotivação e Culturaò......... 46

Tabela 5: Caracterização operacional indicadores de ñPercepção de Desempenhoò. .... 47

Tabela 6: Caracterização operacional indicadores ñCaracterísticas Organizacionaisò... 48

Tabela 7: Estatística Descritiva do comport. Gasto Investimento na Rede Federal........52

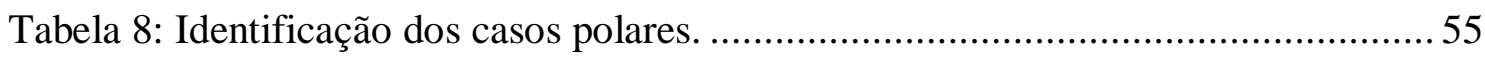

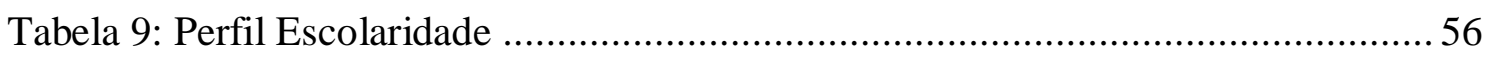

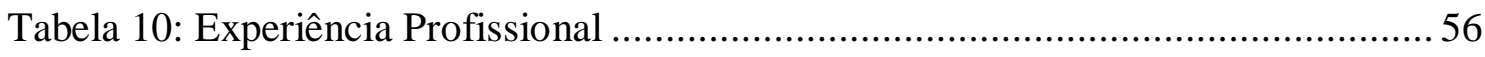

Tabela 11: Experiência em Cargos de Liderança ...................................................... 57

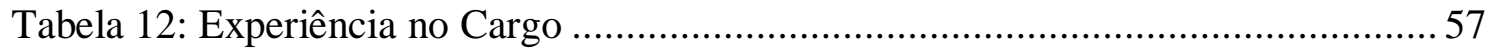

Tabela 13: Contribuição dos Fornecedores ............................................................... 58

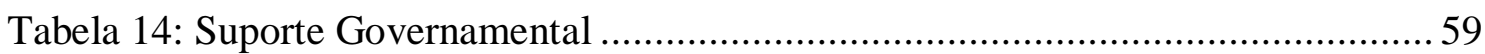

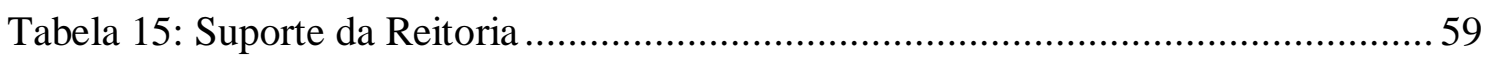

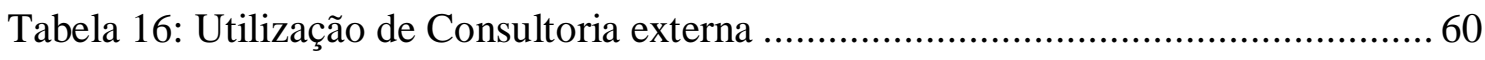

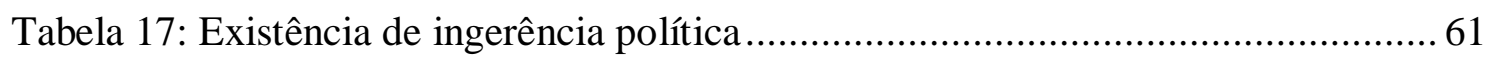

Tabela 18: Grau de Planejamento Orçamentário....................................................... 61

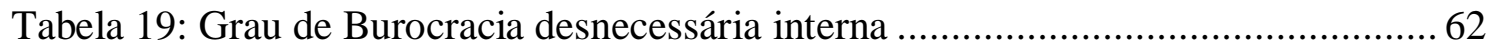

Tabela 20: Grau de Reconhecimento dos bons Funcionários ..................................... 62

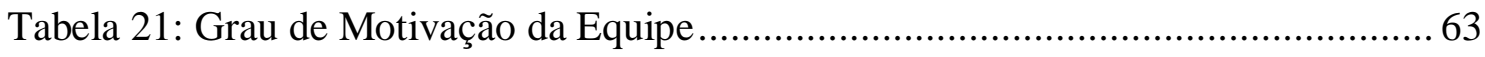

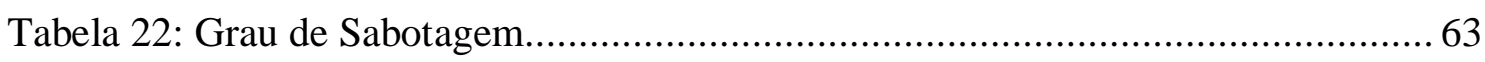

Tabela 23: Grau de Motivação por função comissionada .......................................... 64

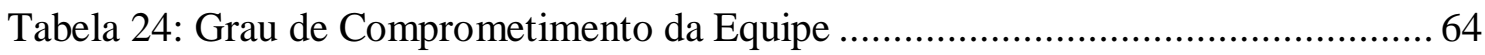

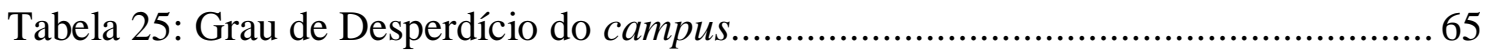

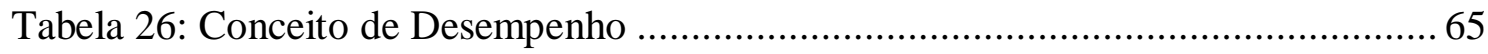

Tabela 27: Produtividade Macroeconômica do Gasto em Investimento ........................66

Tabela 28: Percepção de desperdiço do campus ..................................................... 66

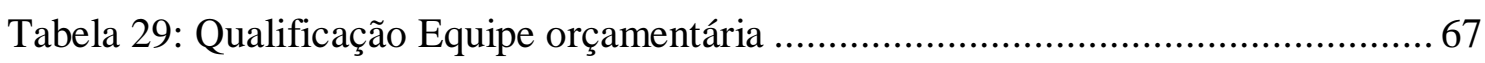

Tabela 30: Experiência Profissional Pregressa dos Servidores ligados ao Orçamento .. 67 
Tabela 31: Tempo de Capacitação da Equipe ligada ao Orçamento 68

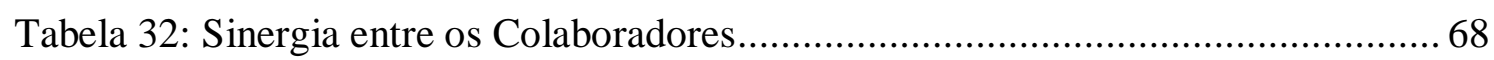

Tabela 33: Sumário das hipóteses ï Indicadores de Capital Humano ............................ 69

Tabela 34: Sumário das hipóteses ï Indicadores de Capital Social............................. 70

Tabela 35: Coeficientes de Regressão ï Características Gerenciais ............................ 71

Tabela 36: Sumário das hipóteses $і ̈$ Indicadores de Características Gerenciais ............. 72

Tabela 37: Sumário das hipóteses ï Indicadores de Motivação e Cultura..................... 73

Tabela 38: Coeficientes de Regressão ï variável Desemp_PD..................................... 74

Tabela 39: Coeficientes de Regressão ï variável Prod_PD .......................................... 74

Tabela 40: Coeficientes de Regressão Ï variável Desper2_PD................................... 74

Tabela 41: Sumário das hipóteses ï Indicadores de Percepção de Desempenho............ 75

Tabela 42: Coeficientes de Regressão Ï variável CapacEqu_CO ............................... 76

Tabela 43: Sumário das hipóteses ï Indicadores de Características Organizacionais.... 76

Tabela 44: Coeficientes de Regressão Ï Modelo Geral .............................................. 77

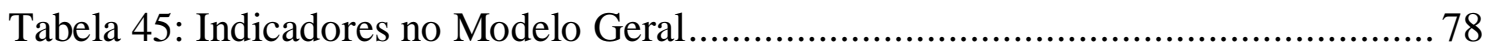




\section{LISTA DE QUADROS}

Quadro 1: Variáveis explic., sinal e pressup. conceituais ñCapital Humanoò. 44

Quadro 2: Variáveis explic., sinal e pressup. conceituais ñCapital Socialò. 45

Quadro 3: Variáveis explic., sinal e pressup. conceituais ñCaracterísticas Gerenciaisò. 45

Quadro 4: Variáveis explic., sinal e pressup. conceituais ñMotivação e Culturaò. 46

Quadro 5: Variáveis explic., sinal e pressup. conceituais గ̃Percepção Desempenhoò.... 47

Quadro 6: Var. explic., sinal e pressup. conceituais ñCaracterísticas Organizacionaisò.48

Quadro 7: Teste dos indicadores de ñCapital Humanoò. 69

Quadro 8: Teste dos indicadores de ñCapital Socialò. ............................................ 70

Quadro 9: Teste dos indicadores de ñCaracterísticas Gerenciaisò............................... 71

Quadro 10: Teste dos indicadores de ñMotivação e Culturaò. ..................................... 72

Quadro 11: Teste dos indicadores de r̃Percepção de Desempenhoò............................ 73

Quadro 12: Teste dos indicadores de Características Organizacionais ....................... 75

Quadro 13: Regressão linear com o Modelo Geral Proposto........................................ 77 


\section{SUMÁRIO}

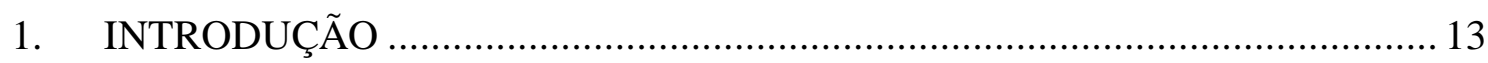

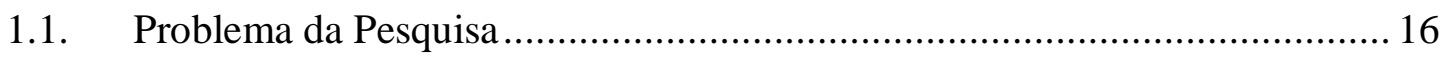

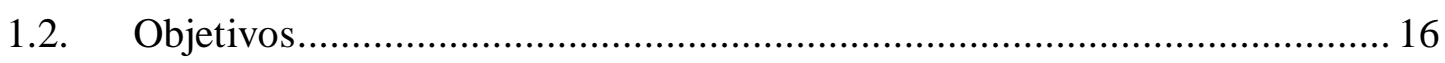

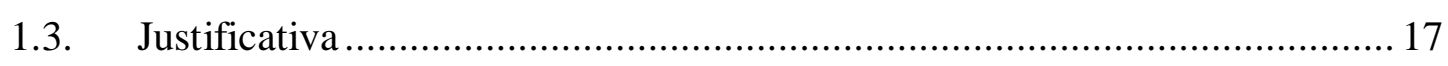

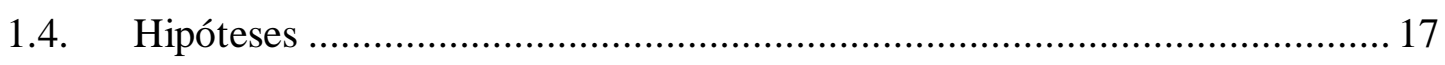

2. ESTADO, QUALIDADE DO GASTO PÚBLICO E INVESTIMENTO .............. 19

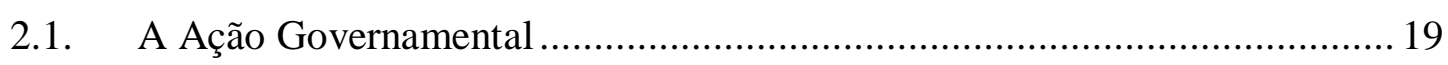

2.2. A Qualidade do gasto e sua Ineficiência no setor Público .............................20

2.3. Investimento e Custeio no Gasto Público: conceito e papel.............................24

3. A REDE FEDERAL DE EDUCAÇÃO PROFISSIONAL …………………….....28

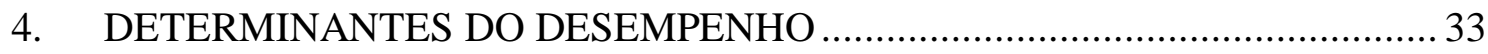

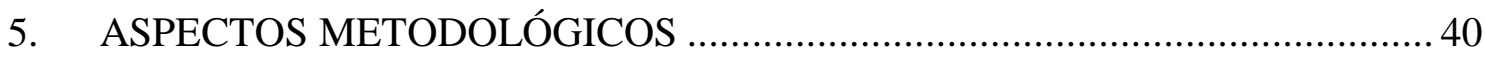

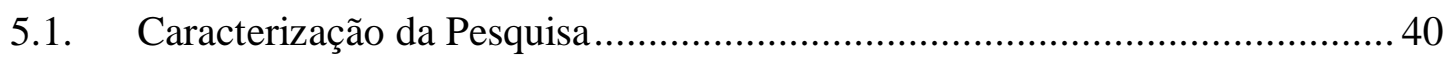

5.2. Universo, Amostra e Amostragem da Pesquisa ............................................... 41

5.3. Modelo Conceitual Teórico ………………………………………………...... 41

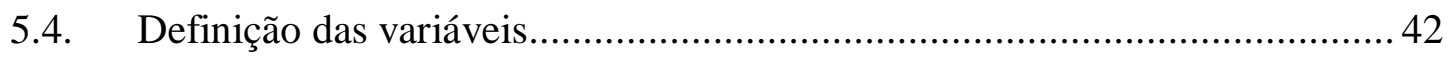

5.5. Pré-testes de aplicação dos questionários ........................................................ 48

5.6. Procedimento para coleta dos dados .......................................................... 49

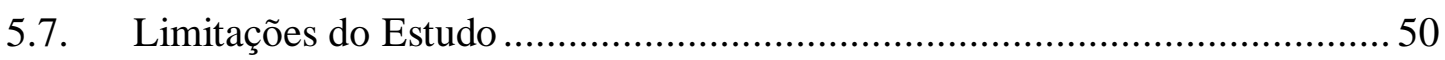

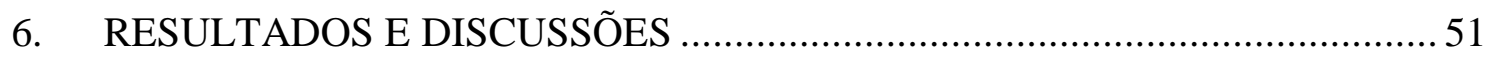

6.1. Descrição da Amostra …………………………………………………........ 51

6.2. Teste de Hipóteses ï Inferências Parciais por Indicador................................. 69

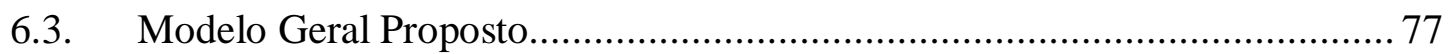

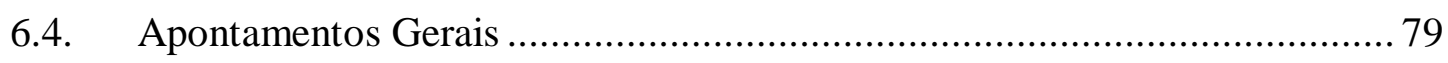




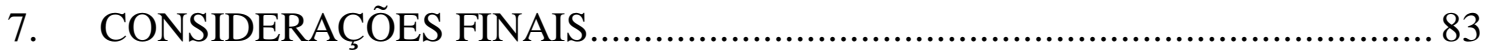

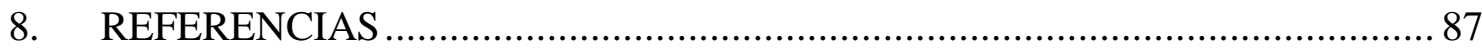

9. APÊNDICE A: Texto de apresentação do Questionário .................................. 94

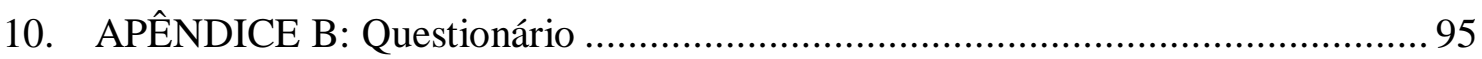

11. APÊNDICE C: Gráfico do Comportamento Orçamentário dos Institutos...............100 


\section{INTRODUÇÃO}

No decorrer da década de 80, sob o impacto de fatores externos e internos, redefiniu-se a agenda pública brasileira. Choques externos, como as crises do petróleo, o colapso do sistema financeiro internacional, os efeitos associados à $3^{\mathrm{a}}$ revolução industrial e à globalização traduziram-se em pressão em prol das políticas de estabilização e ajuste econômico, que culminariam no fim do Estado do Bem Estar Social, em quase todo mundo.

Paralelamente, o Brasil passava por um agravamento do processo inflacionário, uma consciência cada vez maior da deterioração do antigo modelo de Estado, e, principalmente, vivenciava um intenso processo de redemocratização política (DINIZ, 1996).

É nesse contexto que surge a Constituição Federal de 1988 (CF/88), refletindo, por um lado, um conjunto de restrições orçamentárias e financeiras de nível mundial e, por outro, uma demanda interna cada vez maior por políticas sociais e intervencionistas, ao ponto de comprometer a governabilidades interna (MACIEL, 2007). Assim, paradoxalmente, enquanto o mundo inteiro desmantelava as estruturas do Estado do Bem Estar Social, no Brasil, a Constituição Federal de 1988 (CF/88) inovava ao institucionalizar uma agenda de políticas sociais com diretrizes de universalização e igualdade de acesso, típicas de um modelo de Estado de Bem Estar Social (FRANZESE; ABRÚCIO, 2009).

O Estado vai, desta forma, progressivamente, aumentando seus gastos sociais, estendendo aos mais pobres políticas que antes não existiam. Em razão disso, surge no país um boom de políticas pró-pobre que se somaram às tradicionais políticas pró-ricos, os quais continuaram com canal de acesso ao poder, e continuaram obtendo do Estado o que obtinham antes, como crédito subsidiado, proteção comercial às indústrias, cartórios, perdão às dívidas agrícolas, educação universitária, mercado de trabalho protegido, regulação fraca, dentre outros (VELLOSO et al., 2009; CABRAL, 2007). 
Como decorrência de todo esse gasto, e, por conseguinte, a carga tributária saiu de menos de $20 \%$ do Produto Interno Bruto (PIB), na década de 80, para quase $40 \%$ PIB em 2014 (IBPT, 2014).

Nesse contexto, uma das saídas que se apresentam ao país como forma de retomada de taxas mais elevadas de crescimento do PIB perpassa, invariavelmente, pela melhoria dos Gastos Públicos. Para tanto, dois aspectos ganham destaque na literatura sobre o que seria gasto público de qualidade: o primeiro, numa dimensão macroeconômica, diz respeito à necessidade de acréscimos dos gastos públicos em investimento; o segundo, mais operacional, da necessidade de redução das despesas em custeio na prestação dos serviços públicos (REZENDE, 1974; VELLOSO et al., 2009; IPEA, 2006; ROCHA, 2006; TEIXEIRA e RODRIGUES, 2010; MOURA, 2015).

Entretanto, ambos os aspectos estão relacionados, visto que, analisando por um ponto de vista mais simplista, a redução dos gastos públicos em custeio, pode ser uma oportunidade para aumento do gasto em investimento (RIANI, 2002). Desde que não haja modificação da carga tributária e/ou contração de empréstimos pelo Estado. O que relembra a igualdade contábil básica entre poupança e investimento.

Os desdobramentos destes conceitos também perpassam por prismas distintos, relacionando-se, primeiramente, com a contribuição do governo para o processo de acumulação de capital, tendo em vista os objetivos gerais de crescimento econômico; e, em segundo, preocupando-se com o aspecto administrativo e operacional da diminuição dos gastos de custeio, no sentido de realizar os mesmos serviços públicos com o mínimo de recurso possível.

Dessa forma, acredita-se que com o gasto público direcionado a rubrica investimento, haveria, por parte do Estado, um poder de impulsionar o crescimento econômico de forma mais efetiva, em detrimento do gasto direcionado ao custeio. Em razão disso, este 
direcionamento deveria estar presente na execução orçamentária de todos os órgãos públicos. Seguindo esse mesmo raciocínio, também deveria haver direcionamento ao gasto em investimento na execução orçamentária de todas as Instituições de Educação do Sistema Educacional Brasileiro, no qual está inserida os campi da Rede Federal de Educação Profissional e Tecnológica.

As escolas da Rede Federal de Educação Profissional vivem, atualmente, um momento singular em sua história (CARDOZO, 2010), conforme evidenciado no Plano de Expansão I e II do Governo Federal (MEC, 2009). Em números, a quantidade de unidades da Rede saiu de 140 unidades em 2002 para 562 unidades em 2014, um aumento de 400\% em pouco mais de $10 \operatorname{anos}($ BRASIL, 2015).

Isso porque, segundo documento expedido pela Secretaria de Educação Média e Tecnológica ï SEMTEC-, a educação profissionalizante tem caráter ñestratégico para o desenvolvimento nacionalò(BRASIL, 2003, p.5).

Outro ponto que merece destaque é a localização geográfica desses campi no território Brasileiro. Conforme proposto no plano de expansão Fase II, para cada cidade pólo de uma mesorregião deveria haver uma unidade da Rede. Dessa forma, além de ter vivenciado a maior expansão de sua historia, a Rede Federal de Educação Profissional passou a ter uma permeabilidade nas principais cidades do país e do território nacional e, consequentemente, uma capacidade de influenciar o comportamento social e econômico até das regiões mais distantes (PEREIRA, 2008).

Diante destas constatações e considerando a premissa que os gastos em investimento são preferíveis àqueles em custeio, este trabalho se propõe a investigar os principais fatores determinantes da qualidade do gasto público nas unidades da Rede Federal de Ensino Profissional, Científica e Tecnológica. 


\subsection{Problema da Pesquisa}

A partir dessa reflexão, apresenta-se o problema de pesquisa deste trabalho: É possível identificar uma correlação entre o orçamento destinado a investimentos vis-à-vis um modelo teórico de desempenho institucional baseado em algumas variáveis explicativas: capital humano e social, características gerenciais e organizacionais, motivação e cultura, percepção de desempenho?

\subsection{Objetivos}

\subsubsection{Objetivo Geral}

O objetivo geral deste trabalho é identificar e testar possíveis fatores que sejam capazes de explicar o desempenho na execução orçamentária das unidades da Rede Federal de Educação Profissional. Em outras palavras, se é possível identificar causalidades entre variáveis explicativas propostas no modelo geral e o desempenho em qualidade do gasto público, traduzido sob a forma de quantidade de recurso destinado a rubrica investimento.

\subsubsection{Objetivos Específicos}

a) Caracterizar o atual cenário do gasto Público na Rede Federal de Educação Profissional, através do levantamento dos gastos por rubrica por Unidade Gestora Ï UASG;

b) Construir um ranking, utilizando-se do levantamento anterior, das unidades na Rede Federal de Educação Profissional que possuíram melhor qualidade do gasto público;

c) Construir um modelo geral, composto por diversas variáveis independentes, potencialmente capazes de explicar o desempenho das unidades da Rede Federal de Educação Profissional; 


\subsection{Justificativa}

O estudo é justificado por subentender-se que à medida que se conhece os fatores determinantes do sucesso em desempenho das Instituições Públicas de Ensino, tem-se um ganho de eficiência na construção de políticas públicas e no desenvolvimento de tecnologias de conhecimento voltadas para o planejamento e para a gestão dessas Instituições.

Mais especificamente, acredita-se contribuir, de maneira geral, para a sociedade e para as instituições de ensino, em particular, aos gestores públicos e à academia.

Sociedade, na medida em que aumenta o retorno social das ações públicas. Inclusive pelo aprofundamento no tema qualidade do gasto público e pela relevância que este tem alcançado, principalmente, em relação à estratégia da política fiscal recente do governo, de aumento dos gastos sociais, aumento da tributação e supressão dos gastos em investimento. Instituições de Ensino, ao buscar um arcabouço conceitual e empírico para se medir o desempenho dessas Instituições de Educação. Gestores Públicos, pelo esforço para se criar critérios que auxiliam a Administração Pública na tomada de decisão e pela possibilidade de divulgação de situações de benchmarking e, academia, por incentivar estudos acadêmicos envolvendo desempenho de Instituições Públicas, incentivando uma área poucos explorada.

\subsection{Hipóteses}

Considerando o problema explicitado, a pesquisa tem o objetivo de demonstrar a correlação entre as variáveis explicativas e o gasto público em investimento dos Institutos Federais, assim, as hipóteses são:

$\mathbf{H}_{\mathbf{0}, \mathbf{1}}$ Os indicadores de ñCapital Humanoò são determinantes da qualidade do gasto público; $\mathbf{H}_{\mathbf{0}, 2}$ : Os indicadores de ñCapital Socialò são determinantes da qualidade do gasto público; $\mathbf{H}_{\mathbf{0}, 3:}$ Os indicadores de ñCaracterísticas Gerenciaisò são determinantes da qualidade do gasto público; 
$\mathbf{H}_{\mathbf{0}, \mathbf{4}}$ Os indicadores de ñMotivação e a Culturaò são determinantes da qualidade do gasto público;

$\mathbf{H}_{\mathbf{0 , 5}}$ : Os indicadores de ñPercepção de Desempenhoò são determinantes da qualidade do gasto público;

$\mathbf{H}_{\mathbf{0 , 6}}$ : Os indicadores de ñCaracterísticas Organizacionaisò são determinantes da qualidade do gasto público; 


\section{ESTADO, QUALIDADE DO GASTO PÚBLICO E INVESTIMENTO}

\subsection{A Ação Governamental}

O Estudo da Teoria Geral do Estado mostra que o surgimento do Estado imbrica-se, temporal e espacialmente, com o fato de as sociedades necessitarem de dar satisfação a um conjunto, cada vez maior, de problemas de ordem coletiva.

Deste modo, ao surgirem, essas organizações políticas são obrigadas, para resolverem os problemas coletivos, a estabelecerem uma ordem econômica específica, centrada na afetação de recursos econômicos escassos para satisfação de necessidades públicas ilimitadas (ALBANO SANTOS, 2012). Assim, o Estado passa a interferir na economia, com ações que vão desde a regulamentação do mercado até a oferta de bens e serviços. Assumindo diversas responsabilidades inerentes a sua condição de agente.

$\mathrm{Na}$ sua generalidade, para que uma necessidade coletiva transforme-se numa necessidade pública, há que resultar de uma escolha do Estado, constituindo, per si, um ato político. Ora, todo ato político depende da ideologia vigente em sua sociedade e, principalmente, do conceito que estes fazem sobre o Estado e sobre o papel que ele deve exercer (ALBANO SANTOS, 2012). Dessa forma, indiretamente, é a matriz ideológica de uma sociedade que define o tamanho do seu Estado e o papel dele numa determinada economia.

Note-se que os contornos que um Estado possui são moldados por uma combinação de fatores heterogêneos, principalmente, de ordem política, econômica e ideológica (ALBANO SANTOS, 2012).

Assim, em razão dessas necessidades coletivas, da ordem econômica, política e, principalmente, da ideologia de sua sociedade, de que cabe ao Estado a solução dos mais diversos problemas, os Estados atuais têm tomado proporções antes inimagináveis, possuindo 
uma onipresença na vida econômica e social das sociedades modernas, com uma participação no mercado em torno de 30 a $50 \%$.

Ora, esta permanente ação governamental, pela sua própria dimensão a que chegou, acaba tendo uma incidência direta e não negligenciável, na capacidade produtiva do seu país e, por conseguinte, no bem estar de sua população. Visto que, um Estado que possui até 50\% de participação no mercado, sendo ele ineficiente, acaba por tornar ineficiente toda a economia de seu país (CARDOSO, 2015).

Dessa forma, torna-se imperativo ao Governo gerir a máquina do Estado e administrar o uso dos recursos disponíveis, assegurando a máxima satisfação das necessidades coletivas e promovendo o bem-estar da população, sempre de forma eficiente e produtiva.

De outra forma, ao debruçar-se, especificamente sobre o caso Brasileiro, esta imposição por eficiência está plasmado no artigo 37 da CF/88, sendo, por isso, uma obrigação do Estado no cumprimento de suas atribuições (MORAES, 2005; ALEXANDRINO e PAULO, 2010).

Nesse sentido, ganha relevo o conceito de qualidade do Gasto Público, como forma de o Estado cumprir sua missão pelo qual foi criado e, ainda, promover o desenvolvimento e bem estar de sua população.

\subsection{A Qualidade do gasto e sua Ineficiência no setor Público}

O estudo dos gastos públicos relaciona-se com a análise da intervenção do Estado na economia, essencialmente, por meio da obtenção de recursos oriundos da sociedade e a sua realocação na forma de bens e serviços ofertados ao público, para supressão das falhas de mercado (SILVA, 2007).

Nesse sentido, a realocação dos recursos, ou, mais precisamente, a qualidade com que é realizado este gasto é fundamental para que o setor público alcance seu objetivo principal: o 
bem-estar social. Tendo isso em mente, cabe, então, definir o conceito de ñgasto públicoò e de ñqualidade do gasto públicoò. Segundo Riani (2002), os gastos públicos constituem-se:

[...] no principal instrumento de atuação governamental e representam o custo da quantidade e da qualidade dos bens e serviços oferecidos pelo governo. Mediante sua utilização, o governo define suas prioridades em relação à prestação de serviços públicos básicos e aos investimentos a serem realizados (RIANI, 2002. p.52).

Os gastos públicos são, portanto, ña evidenciação das políticas de gestão efetuadas pelos governosò (MAIA et al., 2009. p.4). A palavra ñqualidadeò, por sua vez, pode ter várias definições, uma delas consiste em ño grau de perfeição, de precisão, de conformidade a certo padrãoò. Assim, por interpretação extensiva, o termo ñqualidade do gasto públicoò torna-se um constructo social, no sentido da utilização dos recursos públicos para atendimento a certos padrões considerados positivos.

Outro significado da palavra qualidade é a ñvirtude ou característica de se conseguir o melhor rendimento com o mínimo de erro e/ou dispêndios de energia, tempo, dinheiro ou meiosò. Assim, Chaves (2007) acrescenta:

[...] a melhoria da qualidade do gasto público redunda em melhorar a eficiência desse gasto, ou seja, determinado investimento deverá ser concluído com o menor custo possível e gerar o máximo de benefícios para a sociedade (CHAVES, 2007. p. 845-855).

Nessa lógica de eficiência dos recursos públicos, o Boletim de Desenvolvimento Fiscal do Instituto de Pesquisa Econômica Aplicada ï IPEA (2006) - complementa:

[...] a melhoria da qualidade do gasto público permitiria que as demandas sociais por serviços públicos pudessem ser supridas, pelo menos parcialmente, a custos decrescentes, ou seja, sem acréscimo da carga fiscal. Dessa forma, seria possível conciliar a pressão por mais serviços com a restrição imposta pelo limite à tributação (IPEA, 2006.p.5). 
Entretanto, o que se observa no setor público é seu inverso, diversos trabalhos acadêmicos ressaltam a ineficiência do setor público, deixando explícito o quanto os gastos correntes, de manutenção da máquina pública, podem ser reduzidos sem diminuição da quantidade ou da qualidade dos bens e serviços ofertados. Dentre eles citam-se os trabalhos de Bandiera; Prat e Valletti (2009); Ribeiro e Junior (2006); Afonso, Schuknecht e Tanzi (2005 e 2006); Motta (2010).

O trabalho de Bandiera; Prat e Valletti (2009), ao discutir o enorme desperdício no setor público italiano em função da ineficiência gerencial, se destaca ao distinguirem os desperdícios em dois tipos específicos, a saber:

Desperdícios ativos é tal que a sua presença implica benefício direto ou indireto para
o tomador de decisão pública. Em outras palavras, reduzindo o desperdício poderia
reduzir a utilidade do tomador de decisão. O exemplo clássico é a corrupção em
concursos, em que o funcionário público inflaciona o preço pago por um
determinado bem em troca de um suborno.
Desperdícios passivos, pelo contrário, é tal que a sua presença não beneficia o
decisor público. Em outras palavras, reduzindo o desperdício seria aumentar a
utilidade da decisão. Desperdícios passivos podem derivar de uma variedade de
fontes. Uma delas é que os funcionários públicos simplesmente não possuem as
habilidades necessárias para minimizar os custos. Outra é que os funcionários
públicos não têm nenhum incentivo para minimizar os custos, embora eles são
capazes de fazê-lo. O resultado final dos Desperdícios passivos podem aumentar
brutalmente o preço médio que o setor público despende em sua manutenção
(BANDIERA; PRAT; VALLETTI, 2009, p.1278). (tradução própria)

Dentre as conclusões apresentadas pelos autores, uma das mais interessantes é a de que 83\% do desperdício analisado eram de caráter passivo, ou seja, reflexo de má gestão e má alocação dos recursos. Os autores ainda chamam a atenção que, ainda assim, os governos continuam a investir mais em combate a corrupção do que no melhoramento da máquina administrativa, ou seja, concentra-se mais, não no fato que pode ter os melhores resultados, mas no que a sociedade julga pior moralmente.

Ribeiro e Junior (2006) afirmam, com base em um estudo quantitativo/comparativo na América Latina, pelo método de Análise Envoltória de Dados (DEA), que, no Brasil, poder- 
se-ia economizar em torno de $40 \%$ de seus insumos para produzir o mesmo output, ou seja, ter o mesmo resultado no quesito oferta de bens e serviços. Bastando haver melhoria na eficiência produtiva do setor público. Reitera-se que a comparação é apenas com países da América Latina, fato que os fazem considerar o Brasil com desempenho muito ruim.

Outra pesquisa que ressalta a ineficiência do setor público é a de Afonso, Schuknecht e Tanzi (2005 e 2006) que, após estudos empíricos comparativos com países industrializados e um conjunto de emergentes, construíram e avaliaram indicadores sobre o desempenho dos serviços e a eficiência da despesa pública. Mesmo estando sujeitos a algumas limitações, os indicadores construídos e as técnicas utilizadas na avaliação da eficiência relativa evidenciaram que os retornos marginais dos gastos públicos são decrescentes independentemente do grupo de países considerados. Em síntese, o gasto mostrou-se mais eficiente nos países em que o setor público é comparativamente menor.

Seguindo os resultados desse autor, fica evidente o quanto podem ser reduzidos os gastos de manutenção da máquina pública no Brasil, a lembrar-se que, atualmente, quase $40 \%$ do PIB é destinado ao setor público, enquanto no Estados Unidos, por exemplo, menos de 25 $\%$ do PIB é destinado ao Estado (IBPT, 2014).

Ainda em relação ao Brasil, pesquisa realizada por Motta (2010), avaliou a contribuição do sistema de compras públicas no âmbito da Administração Direta do Poder Executivo na busca de maior eficiência do gasto público. A conclusão a que o autor chegou foi que o sistema brasileiro de compras públicas não contribui substancialmente para a melhora da eficiência do gasto público.

Pela exposição, fica clara a má alocação de recursos, bem como a inadequada utilização desses recursos existentes. Há possibilidades para a diminuição das despesas de custeio, o que, por conseguinte, abriria espaço para o aumento dos investimentos públicos, o que pode aumentar a capacidade produtiva da economia. 


\subsection{Investimento e Custeio no Gasto Público: conceito e papel}

O conceito de investimento utilizado pelo setor público ganhou destaque, notadamente, a partir da difusão das ideias de Keynes (1936) sobre o papel do Estado na economia, em que alertava sobre a relevância dos investimentos do setor público na estabilização dos ciclos econômicos (OLIVEIRA, 2009; JUNQUEIRA, 2011). Posteriormente, Kalecki (1954) também ressalta os efeitos do investimento sobre a determinação do nível e da dinâmica da atividade econômica (GONZALES et al., 2014).

Entretanto, a definição do conceito de investimento e de custeio não pode ser feita com base exclusivamente na distinção entre os efeitos que estes gastos possuem sobre a economia, visto não serem consensuais esses posicionamentos (JUNQUEIRA, 2011). Nomeadamente por existirem alguns trabalhos conclusivos em que demonstram que o crescimento econômico pode ser gerado independentemente de sua classificação em custeio ou investimento, principalmente quando destinado a educação e pesquisa/desenvolvimento (REZENDE, 1974). São exemplos as pesquisas de Lucas (1988), a qual argumenta que a despesa pública em educação aumenta o nível de capital humano, e Romer (1990), que chama a atenção para a relevância das despesas em pesquisa e desenvolvimento (P\&D), ambas sendo importantes para o crescimento econômico a longo prazo.

De outro modo, Junqueira (2011) resume que a principal característica relevante sobre a distinção conceitual entre gastos em custeio e investimento na classificação orçamentária reside em que:

(...) toda despesa de capital cria condições materiais duradouras para a provisão de bens/serviços, estendendo sua vida produtiva no médio e longo prazo ï como nas obras de construção civil (edifícios, estradas, usinas hidroelétricas), na compra de máquinas, equipamentos e até na aquisição de livros, cujas vidas úteis são mais reduzidas (JUNQUEIRA, 2011.p. 7). 
Assim, as despesas que visam criar capacidade, permitindo aumentar a oferta de bens/serviços são classificadas como investimento. Conceito que se aproxima da definição de Formação Bruta de Capital Fixo, a qual é definida pelo IBGE (2015) como:

(...) a ampliação da capacidade produtiva futura de uma economia por meio de investimentos correntes em ativos fixos, ou seja, bens produzidos factíveis de utilização repetida e contínua em outros processos produtivos por tempo superior a um ano sem, no entanto, serem efetivamente consumidos pelos mesmos (IBGE, 2015. p. 2).

Note-se que essa definição de investimento se refere principalmente a obras, instalações, máquinas e equipamentos, mas também engloba $\tilde{n}(. .$.$) o valor dos serviços ligados$ à instalação dos bens de capital, dos bens e serviços incorporados aos terrenos, assim como o valor dos gastos inerentes à transmissão de propriedades de terrenos, edifícios e outros bens de capital existentesò (IBGE, 2015. p. 4).

Todavia, a contabilidade pública ao estatuí as normas para o Direito Financeiro, utilizou-se destes conceitos, inserindo-os na Lei n. ${ }^{\circ}$ 4.320/1964 e atualizações posteriores.

Assim, de acordo com a Lei 4.320/64:

Art. $12, \S 4^{\circ}$ Classificam-se como investimento as dotações para o planejamento e a execução de obras, inclusive as destinadas à aquisição de imóveis considerados necessários à realização destas últimas, bem como para os programas especiais de trabalho, aquisição de instalações, equipamentos e material permanente e constituição ou aumento do capital de empresas que não sejam de caráter comercial ou financeiro.

Os gastos com manutenção da máquina que objetivam manter o funcionamento, sem aumento da oferta de bens ou serviços são classificados como despesa corrente - custeio. Definido pela Lei n. ${ }^{\circ} 4.320 / 1964$ como ñas dotações para manutenção de serviços anteriormente criados, inclusive as destinadas a atender a obras de conservação e adaptação de bens imóveisò (Lei n. ${ }^{\circ}$ 4.320/1964, art.12, § 1º). 
Note-se que, embora aparentemente opostos em sua conceituação, Rezende (1974) afirma que, na prática, tanto os gastos em custeio como os em investimento são considerados bens substitutos entre si, dado que a compressão das despesas em custeio é uma alternativa para liberação de recurso à despesa de capital. Não havendo, assim, aumento da dívida com empréstimos nem aumento de carga tributária.

Ratificando o posicionamento de Riani (2002), pela qual fica evidente que quanto maior o volume de recursos gastos pelo governo em compromissos correntes, menor será sua capacidade de poupança e, em conseqüência, será reduzida a sua possibilidade de realizar investimentos.

Ressalta-se que nessa relação entre despesas de custeio e de investimento também é, comumente, observado que, logo após o ente estatal despender recursos financeiros na rubrica investimento, este obtém, em decorrência, um aumento dos gastos correntes, para manutenção dessas estruturas e/ou equipamentos adquiridos. O que pode comprometer sua capacidade de investimento futuro. Dessa forma, há que entender que todo esse efeito positivo gerado pelo gasto em investimento é resultado, a priori, do ñom investimentoò, ou seja, aquele fruto do planejamento e da priorização do interesse social.

De toda forma, em geral, os estudos mostram que o consumo do governo (gastos correntes) tem impacto negativo ou nulo sobre o crescimento econômico de longo prazo, enquanto os gastos em investimento possuem comportamento inverso, afetam positivamente a taxa de crescimento de longo prazo (ROCHA, 2006; MOURA, 2015; ASCHAUER, 1989). Ganhando destaque os gastos realizados em investimento, em detrimento dos realizados em custeio (REZENDE, 1974).

Nesse sentido, algumas pesquisas demonstram essa relação, são exemplos: Grier e Tullock (1989) usando dados de 115 países, no período pós-guerra, mostraram que o aumento 
das despesas correntes do governo afeta negativamente o crescimento do PIB. Enquanto os gastos em investimento fornecem um ambiente que estimula o crescimento econômico.

Possas (1999) ressalta, ainda, que essa centralidade do papel dos gastos em investimento numa economia não se dá em razão do peso do investimento no produto de uma economia, visto ser ele inferior ao consumo, mas pela sua maior autonomia em relação ao nível de atividade. O que o torna ñuma variável-chave para a determinação endógena não apenas desse mesmo nível de atividade, como também de suas variações, eventualmente, de suas flutuações e mesmo de sua possível instabilidadeò(POSSAS, 1999. p. 31).

Para Candido Jr. (2001), que avalia empiricamente a relação entre gastos públicos (agregados) e crescimento econômico no Brasil entre 1947 ï 95, a cada aumento de 1\% nos gastos em consumo, tem-se, como conseqüência, um decréscimo de $0,02 \%$ do produto. Já quando se inclui gastos em investimento, a relação inverte-se, passando a ser positivo o crescimento econômico.

Pesquisas como a de DeLong e Summers (1992 apud REIS, 2008) afirmam que os países que obtiveram as maiores taxas de crescimento econômico em anos sucessivos foram àqueles que mais investiram em máquinas e equipamentos, porque esses bens provocaram aumento da tecnologia da economia e, por conseguinte, demandaram mais pesquisas em tecnologia, os quais são o núcleo da mudança industrial.Note-se que os gastos em investimento têm como característica intrínseca proporcionarem grande externalidade (REIS, 2008), ou seja, como conseqüência de um investimento tem-se não só o efeito pretendido, mas outros decorrentes, tão benéficos quanto.

Deste modo, ganha relevância a função do investimento público ao antecipar e conduzir o desenvolvimento geral do país, a partir de investimentos não atrativos ao setor privado, mas essenciais ao desenvolvimento econômico. Assim, a partir do gasto em investimento público arrasta-se o investimento privado. Pois ele, entre outras coisas, proporciona economia às 
empresas privadas (REIS, 2008). Essas economias decorrem da redução dos custos de produção que o produto do investimento público proporciona, impactando na produtividade e na oferta das empresas.

Outro ponto destacado por Lopez e Cardim (2009) é o sentimento positivo gerado pelo investimento público, ao criar expectativas mais seguras de retorno aos investimentos dos empresários. Propiciando um ambiente de mais investimentos privados e geração de emprego.

Nesse contexto, é importante ressaltar o efeito de retroalimentação, quando, a partir do investimento inicial pelo Estado, verifica-se um crescimento da economia, e, quando a economia cresce, o governo tem condições de gastar mais, em decorrência do aumento da arrecadação, que sustenta a continuidade do ciclo de crescimento.

Em resumo, se por um lado o investimento público acarreta investimento privado, o induzido. Por outro lado, o da oferta, o investimento público constitui demanda autônoma que incentiva o uso de capacidade ociosa ou a extensão da capacidade produtiva de setores que, de outra forma, não teriam estímulos para serem produzidos (REIS, 2008).

\section{A REDE FEDERAL DE EDUCAÇÃO PROFISSIONAL}

Embora a educação profissional tenha início no Brasil há mais de cem anos, em 1909, com a criação das Escolas de Aprendizes e Artífices, sua trajetória, enquanto política pública, não foi diferente de outras políticas governamentais (RUA, 1998). A política da educação profissional foi marcada, historicamente, por grandes intervenções estatal, seguidas de momentos de completo ostracismo, por conseguinte, seguiram-se avanços em certas áreas contrapostas com retrocessos em outras. Essas idas e vindas foram responsáveis por diversas mudanças estruturais, pedagógicas e institucionais, fato que, por vezes, se mostraram equivocadas ou mal planejadas (BARTHOLO, 2011). 
Entretanto, ganha relevância para este estudo, especificamente, a historia recente da educação profissional, quando, em 2002, da eleição do presidente Luiz Inácio Lula da Silva.

Logo de início, em 2003, a Secretária de Educação Média e Tecnológica Ï SEMTECpublicou um documento em que explicita a relevância que a educação profissional possui, fazendo a seguinte declaração:

\begin{abstract}
A educação profissional e tecnológica tem que ter, necessariamente, a intencionalidade estratégica do desenvolvimento, recusando, pois, reduzir o seu alcance a mera adaptação da formação escolar e para-escolar a necessidades dos empregadores, das forças vivas, do mercado de trabalho, sempre imprecisamente esclarecidas, o que vem a ser, em regra, definidas em função do estado conjuntural de diversas relações de força.

O esforço aqui encetado pela Secretaria de Educação Média e Tecnológica do Ministério da Educação - SEMTEC/MEC almeja destacar os compromissos deste governo com a educação básica, a redução das desigualdades sociais, o respeito e o fortalecimento da cidadania, reconhecendo em todos os momentos que à educação profissional e tecnológica cabe uma posição estratégica importante como elemento criativo de alavancagem, junto com outras políticas e ações públicas, para o desenvolvimento socioeconômico do Brasil (Grifo Nosso) (BRASIL, 2003, p.5).
\end{abstract}

Um segundo passo tomado pelo governo foi a revogação da Lei 8.948/94, que proibia a criação de novas unidades de ensino profissionalizante sem que fosse realizada parceria com entes estatais, municipais ou da sociedade civil. Dessa forma, com a nova Lei (11.195/2005) deu-se início a uma série de ações que possibilitou ao Estado a implantação de novas unidades de ensino técnico sob sua tutela.

Assim, ainda em 2005, iniciou-se a Fase I da Expansão da Rede Federal de Educação Técnica e Tecnológica, com a implantação de 64 novas instituições, distribuídas em: 47 UNEDô, 4 campi da UTFPR, 5 Escolas Técnicas Federais e 4 Escolas Agrotécnicas Federais (BARTHOLO, 2011). Em 2007 com o Decreto 6.301, instituiu-se o Sistema Escola Técnica Aberta do Brasil ï e-Tec Brasil, com o objetivo de ampliar a oferta e, conseqüentemente, aumentar o acesso à educação profissional pública e gratuita no interior do país e a na periferia das grandes cidades. Para o programa acontecer, este utilizaria de convênios 
firmados entre as Instituições de Ensino Públicas, principalmente os IF's, juntamente com os Estados, Municípios e Distrito Federal. Fato que proporcionaria aos Institutos Federais expandir sua atuação ainda mais no interior dos estados. Dando continuidade à expansão da Rede Federal de Educação Profissional, em 2007 o governo lança a Fase II da expansão, que teve como lema ñUma escola técnica em cada cidade pólo do paísò(BRASIL, 2007).

O Plano de Expansão da Rede Federal de Educação Tecnológica - Fase II constituise na iniciativa [...], de implantar, [...] novas unidades na Rede Federal de Educação Tecnológica, oferecendo ao país condições favoráveis à formação e qualificação profissional nos diversos níveis e modalidades de ensino, suporte ao desenvolvimento da atividade produtiva, oportunidades de geração e disseminação de conhecimentos científicos e tecnológicos e estímulo ao desenvolvimento socioeconômico em níveis local e regional (BRASIL, 2007, p.6).

De acordo com Pereira (2008), a Fase II da expansão:

[...] toma como base a identificação de cidades-pólo, elevar a contribuição da rede federal no desenvolvimento sócio-econômico do país e concorrerá, sobretudo com a interiorização, para uma mais justa ordenação da oferta de EPT, ao incluir locais historicamente postos à margem das políticas públicas voltadas para esta modalidade (Grifo Nosso) (Pereira (2008, p.90).

Prosseguindo com a expansão, em 28 de dezembro de 2008, a Lei n 11.892 institui a Rede Federal de Educação Profissional, Científica e Tecnológica e cria os Institutos Federais de Educação, Ciência e Tecnologia, com a fusão dos CEFET's com as Escolas Agrotecnicas.

A transformação vivenciada pela rede federal alterou significativamente o seu perfil institucional, uma vez que, sempre limitados ao ensino técnico, se tornavam agora, como Instituto Federal (IF), instituições com as mesmas prerrogativas legais, administrativas e pedagógicas das Universidades Federais, e, dessa forma, podendo oferecer cursos em diversas modalidades e níveis de ensino, do técnico ao doutorado.

De acordo com a exposição de motivos encaminhada pela SETEC/MEC ao senhor Presidente da República, os IF's constituem-se em um arranjo educacional que: 
[...] articula, em uma experiência institucional inovadora, todos os princípios que informaram a formulação do Plano de Desenvolvimento da Educação. Esse arranjo pode abrir excelentes perspectivas para o ensino médio, hoje em crise aguda. Por meio de uma combinação virtuosa do ensino de ciências naturais, humanidades e educação profissional e tecnológica, os Institutos Federais podem colaborar para recompor a espinha dorsal do ensino médio público (BRASIL, 2008).

Com todas essas mudanças, em 2014 os IF's totalizavam 562 campi, pertencentes a 38 Institutos Federais distintos e distribuídos por todo território brasileiro.

Figura 1: Evolução das escolas profissionais no Brasil.

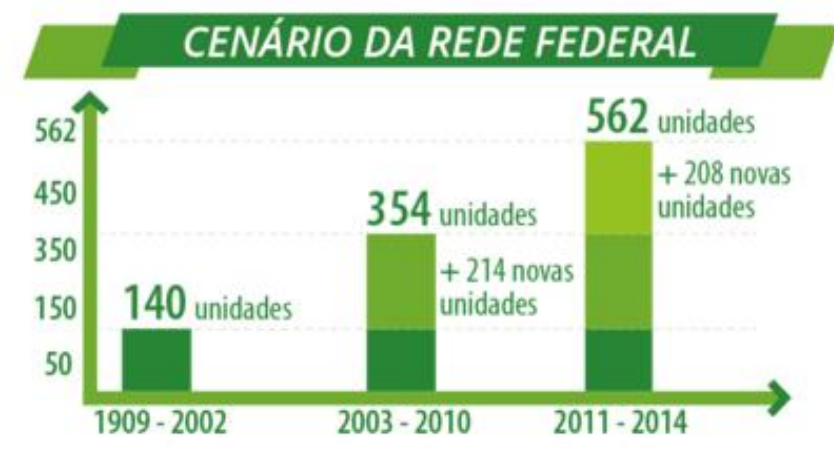

Fonte: Figura obtida em http://redefederal.mec.gov.br/, acessado em 22/08/2015.

Figura 2: Distribuição das unidades da Rede Federal de Educação Profissional pelo país.

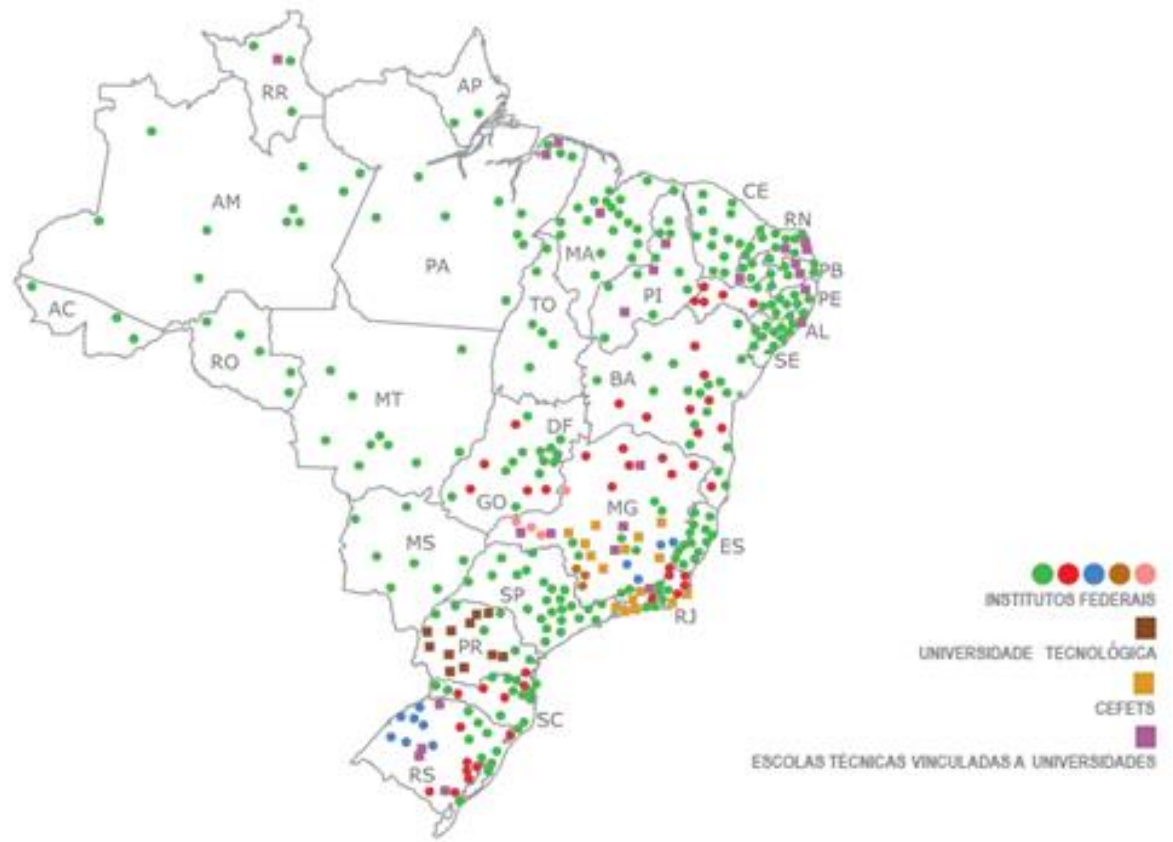

Fonte: Figura obtida em http://redefederal.mec.gov.br/, acessado em 22/08/2015. 
È nesse contexto que se posiciona a Rede Federal de Educação Profissional, com a responsabilidade de ensino, pesquisa e extensão, assim como nas universidades, entretanto, com a missão de contribuir para o desenvolvimento sócio-econômico local e regional, em razão de sua permeabilidade em todos territórios nacional. 


\section{DETERMINANTES DO DESEMPENHO}

Inicialmente, buscaram-se pressupostos teóricos na literatura no intuito de fundamentar a construção dos indicadores, entretanto, nada foi encontrado que comungasse perfeitamente com o pretendido neste trabalho. Assim, por analogia, utilizaram-se, como referência, trabalhos que tratam do desempenho de empresas privadas, adequando alguns pressupostos, julgados pertinentes, ou acrescentando outros por adequação lógica.

Dessa forma, ao final, obtiveram-se vinte e quatro variáveis independentes selecionadas pelo seu potencial poder de explicação, visto que estas já se mostraram relevantes em outros trabalhos sobre desempenho organizacional.

De modo a facilitar a construção teórica dessas variáveis, os determinantes de desempenho foram agrupados em seis constructos, de acordo com sua natureza:

1. Capital Humano;

2. Capital Social;

3. Características Gerenciais;

4. Motivação e Cultura;

5. Percepção de Desempenho;

6. Características Organizacionais.

O primeiro constructo é o ñCapital Humanoò, e diz respeito ao conjunto de atributos pessoais do Gestor, ao estoque de experiência, vivências e habilidades adquiridas ao longo da vida e que o possibilita melhor capacidade para lidar com problemas organizacionais, buscar soluções e criar estratégias (COOPER et al.,1994).

Os principais fatores de ñCapital Humanoò potencialmente explicativos para o desempenho no setor público utilizados neste trabalho foram: a) Educação/Escolaridade; b) Experiência profissional; c) Liderança; e, d) Experiência Gerencial. 
Lussier e Pfeifer (2001) tentando entender o motivo do fechamento de algumas empresas nos Estados Unidos, numa amostra de 350 empresas, identificou na variável Educação e na variável staff (colaboradores) significância estatística que explicasse tal comportamento. Tornando-se relevante na determinação do desempenho organizacional.

Van Praag (2003), com uma amostra de 271 empreendedores, entre 20 e 32 anos, sumarizou diversas variáveis explicativas do desempenho das empresas, e identificou nas variáveis ñExperiência Profissional pregressa do Gestorò e ñLiderançaò duas variáveis relevantes na determinação do sucesso do empreendedor. Além de que, em seu trabalho, a ñExperiência como Gestorò, seja ela no ramo de negócio ou em qualquer outra atividade ocupacional, demonstrou proporcionar maiores chances de sobrevida a empresa.

O ñCapital Socialò consiste nos recursos acessados por meio de parcerias, redes de contatos e relacionamentos, todos externos ao Instituto Federal. Elas podem originar-se tanto por via formal, pelo relacionamento com outros órgãos públicos, como por via informal, através de relacionamentos do Gestor com pessoas ou empresas. Alguns dos potenciais fatores explicativos do desempenho do setor público utilizados nesse trabalho são: a) Instituições Públicas Parceiras; b) Consultoria Especializada; e, c) Cooperação externa.

Raifur (2013), analisando 410 empresas do estado do Paraná, no intuito de identificar fatores determinantes do sucesso dessas empresas, encontrou nas parcerias realizadas entre estas e bancos, e entre estas e fornecedores, uma significância estatística que o fez afirmar que as parcerias são o núcleo do Capital Social. Assim, por similaridade, acredita-se que uma parceria entre o Campus e sua Reitoria e entre o Campus e alguns fornecedores, poderiam ajudar no desempenho da instituição, visto que àquela poderia contribuir com recursos financeiros, pessoal ou orientação na tomada de decisão, enquanto estes poderiam contribuir solucionando problemas ou os minimizado. O mesmo ocorre com as ñnnstituições Públicas Parceirasò. 
Por ñCaracterísticas Gerenciaisò entendem-se os métodos e técnicas inseridos na estrutura administrativa pelo Gestor, em outras palavras, é o estilo de Gestão do Diretor, os quais são responsáveis por organizar, planejar, coordenar, executar e controlar. Alguns dos potenciais fatores explicativos para o desempenho do setor público utilizados nesse trabalho são: a) Planejamento; b) Ingerência política; c) Burocracia; e, d) Reconhecimento Profissional.

Pesquisas como as de Schaefer (2012), Raifur (2013), SEBRAE/SP (2008) obtiveram significância estatística ao analisarem o motivo do sucesso em desempenho de micro e pequenas empresas e, assim, evidenciaram que o planejamento de uma empresa, tanto antes da abertura quanto após, em seu funcionamento, é fundamental para a determinação de sua sobrevida. Sendo considerada uma variável determinante do desempenho organizacional.

Outra variável relevante trata-se do ñgrau de ingerência políticaò dentro do campus. Desde a publicação do artigo ñThe study of Administrationò, por Woodrow Wilson, em 1887, e do livro ñPolitics and Administrationò, por Frank Goodnow, em 1900, criou-se uma diferenciação entre Administração Pública e Política, diferenciação esta associada ao propósito de superação das práticas de apadrinhamento, patrimonialismo e ingerências políticas, típicas da administração pública daquela época (OSLAK, 1982). Assim, a administração científica concebia a administração pública como o espaço da execução, pelo Executivo, de políticas públicas definidas na esfera da política (HENRY, 1975). Dissociando o executar completamente dos jogos políticos próprios da política pública (FARAH, 2011).

Nessa perspectiva, para esses autores, quanto mais ingerência política inseridos na administração pública, menor o desempenho organizacional final.

A próxima variável refere-se às disfunções do modelo burocrático, esta vem, desde o fim da II Guerra Mundial, sendo alvo de criticas (SECCHI, 2009), ganhando evidência criticas de autores como Simon (1947), Waldo (1948), Merton (1949), além de quase todos os 
autores favoráveis ao modelo de Administração Pública do tipo Gerencial. Basicamente as criticas se estruturam sobre os efeitos negativos que as disfunções burocráticas provocam nas organizações, quais sejam: prescrição estrita as tarefas, baixo estimulo e motivação dos colaboradores, resistência às mudanças, baixa inovação, desvirtuamento de objetivos provocado pela obediência acrítica às normas. De acordo com esses autores, o excesso burocrático constitui um empecilho à gestão pública baseada em valores de eficiência, eficácia e competitividade. Sendo considerada como um gerador de efeitos negativos sobre o desempenho organizacional.

De outro lado, ao debruçar-se sobre a variável ñReconhecimento Profissionalò, nota-se que esta tem origem na teoria proposta por Maslow (1954), a qual parte do princípio de que os motivos que movimentam o comportamento humano originam-se de dentro do próprio indivíduo, assim, o autor enumera, de forma hierárquica, cinco níveis de motivação (fisiológicas, segurança, sociais, estima e auto-realização). Quanto às necessidades de estima, o autor explicita que são constituídas pelos desejos de respeito próprio, sentimento de realização pessoal e de reconhecimento por parte dos outros. Assim, o reconhecimento profissional torna-se um motivador não-financeiro determinante do desempenho organizacional.

Nesta esteira de raciocínio, segue o construto ñMotivação e Culturaò, a qual consiste num conjunto de elementos intangíveis que uma instituição possui e que determinam seu desempenho final. Estudos relacionados à influência de fatores motivacionais e culturais na performance organizacional não são novos. As experiências de Taylor com a fragmentação do trabalho e a simplificação das tarefas, ou as experiências de Elton Mayo em Hawthorn avaliando influências sociais, ou ainda, os experimentos com grupos semiautônomos nas fábricas da Volvo em Kalmar e Uddewala investigaram a relação entre formas específicas de gestão de pessoas e impacto sobre a produtividade. 
Assim, alguns dos possíveis fatores explicativos para o desempenho do setor público com base na ñMotivação e Culturaò utilizados nesta pesquisa são: a) Motivação; b) Sabotagem dos colaboradores; e, c) Comprometimento Organizacional dos colaboradores.

Para Gil (2001 p. 201), a motivação pode ser entendida como ño principal combustível para a produtividade da empresaò. Nesse sentido, Reinhardt e Castro (2015) afirmam, após analisar o setor produtivo de uma empresa calçadista, que a motivação na equipe assegura o futuro do negócio, garantindo uma alta produtividade, qualidade e desempenho. (REINHARDT, CASTRO; 2015). Silva (2001) afirma que a falta de motivação dos colaboradores faz com que eles, não sendo capazes de pedir demissão, criem formas de afastamento, absenteísmo, apatia, sabotagem, impactando diretamente na qualidade do trabalho, e, consequentemente, no desempenho geral da empresa. Possuindo um efeito negativo sobre o resultado da organização.

Mowday et al.(1979) define ñcomprometimentoò como sendo algo que vai para além de uma corrente comportamental. Para eles o ñcomprometimentoò possui uma perspectiva atitudinal, sendo muito mais que uma postura de lealdade passiva para com a organização, envolvendo um relacionamento ativo e de busca do seu bem-estar.

O constructo ñPercepção de Desempenhoò diz respeito à necessidade de se captar o conceito de desempenho orçamentário idealizado pelo Gestor. Esta percepção irá influenciar os comportamentos, que afetarão, por conseguinte, o desempenho da organização. Assim, acredita-se que a percepção de desempenho impacta diretamente no envolvimento e comprometimento, de maneira que quanto mais este conceito se aproximar do conceito tratado neste trabalho, mais haverá busca desse Gestor por esse resultado.

Os principais fatores de ñPercepção de Desempenhoò potencialmente explicativos do comportamento orçamentário no setor público utilizados neste trabalho foram: a) Desperdício; b) Conceito de Desempenho Orçamentário; e, c) Conceito de Produtividade do gasto. 
A primeira variável refere-se ao ñdesperdício dentro do campusò, o qual já foi citado no referencial teórico, demonstrando como o recurso público é mal gasto, fato que abre margem de economia das mais diversas formas. Nessa perspectiva, o pressuposto é que quanto maior o desperdício dentro da instituição, menor será a chance de se obter qualidade no gasto público. Assim, Instituições mais enxutas, sem gastos desnecessários, são as que conseguem destinar maior quantidade de recurso a rubrica investimento.

As duas variáveis seguintes foram inseridas no intuito de identificar o conceito de o gasto publico do Gestor. A primeira, o questiona se ele considera o gasto em investimento é um gasto eficiente. A segunda, se o gasto em investimento é, em termos macroeconômicos, mais eficiente que o gasto em custeio. Por fim, o último constructo relevante para determinação do desempenho das empresas privadas utilizado neste trabalho, trata-se das ñCaracterísticas Organizacionaisò. Esse constructo perpassa pela: a) qualidade do Staff; b) experiências anteriores do Staff; c) capacitação da equipe; e, d) sinergia da equipe.

Conforme ressaltado anteriormente, Lussier e Pfeifer (2001) identificou na variável staff (colaboradores) significância estatística que explica o desempenho de permanência no mercado em 350 empresas. Já Bruno et al.(1987) evidenciou que 90\% dos proprietários de empresas privadas fechadas julgavam possuir um staff ineficiente.

Kaplan e Norton (1992) incluem junto à perspectiva de òcapacitação dos empregadosò, os conceitos de motivação, empoderamento e alinhamento aos pressupostos estratégicos da organização. Para os autores, há uma relação causal entre as seguintes perspectivas: melhorar a capacitação de empregados (aprendizado e crescimento), melhorará a eficiência dos processos, deixando os clientes mais satisfeitos e com intenção de comprarem novamente, e, consequentemente, a margem de lucro da empresa aumentará (KAPLAN; NORTON, 1992). Assim, capacitação dos colaboradores redunda em desempenho organizacional. 
Por sinergia entende-se o efeito resultante da ação de vários agentes quando atuando de forma coordenada por um objetivo comum. Assim, diz-se que o resultado do todo supera a soma das partes, caso atuassem individualmente (WOOD, 1999). Dessa forma, organizações com características sinérgicas entre seus colaboradores possuem, por conseguinte, maior desempenho. 


\section{ASPECTOS METODOLÓGICOS}

\subsection{Caracterização da Pesquisa}

A pesquisa pode ser classificada como um estudo exploratório, visto que visa proporcionar uma visão geral de um determinado fato, visão esta do tipo aproximativo. E foi conduzida de duas maneiras distintas, a depender da fase em que se posicionava, entretanto, utilizando-se de uma abordagem unicamente quantitativa.

No primeiro momento, realizada com procedimentos documentais, por utilizar como fonte os dados disponíveis nos sítios do Portal da Transparência. No segundo momento, a partir de dados obtidos por um levantamento realizado junto aos gestores dos Campi da Rede Federal de Educação Profissional.

Na dimensão de tempo, a pesquisa tem um caráter transversal, ou seja, os resultados retratam a situação num dado momento do tempo, mais precisamente no ano de 2015 , ano da coleta dos dados realizados junto aos gestores dos campi (COOPER; SCHINDLER, 2003).

Com relação ao ambiente de pesquisa, os respondentes foram os Diretores Gerais, Diretores de Administração e Coordenadores de Administração destas Unidades, os quais responderam ao instrumento, tendo por base os dados objetivos pessoais e de seu Instituto de origem, mas, também, retrataram suas percepções subjetivas, cujas circunstâncias que o cercam podem ter exercido influência na resposta. Dessa forma, o ambiente de pesquisa caracteriza-se como de campo em condições de rotina real (KERLINGER, 1980).

Já quanto à estratégia de análise desses dados, primeiramente foi feito um ranqueamento do comportamento orçamentário desses campi, classificando os campi em ordem crescente de acordo com a porcentagem de despesa em investimento despendida. Paralelamente, foi feito um levantamento junto aos gestores dessas unidades, onde se obteve os dados dos fatores explicativos daquele desempenho, os quais foram tratados, sistematizados e submetidos ao 
teste estatístico de Regressão Linear Múltipla, numa tentativa de se desvelar padrões de comportamento subjacentes.

\subsection{Universo, Amostra e Amostragem da Pesquisa}

O universo desta pesquisa é formado pelas unidades da Rede Federal de Ensino Profissional, Científica e Tecnológica. Dada a dificuldade de acesso a esses gestores e a necessidade de uso de algumas estratégias adicionais de abordagem dos respondentes, o universo foi delimitado, por conveniência, aos campi categorizados pelo Ministério da Educação (MEC) como pré-expansão, configurando estes a amostra do trabalho.

Ressalta-se que a característica básica dos campi categorizados pelo MEC como préexpansão é possuir mais de 05 anos de existência, e, como consequência disso, possuir altas despesas de custeio na manutenção dessas estruturas físicas já construídas, diferentemente dos campi recém-criados. O que os tornam mais adequados ao objetivo da pesquisa.

Com relação à amostragem, ela foi definida pela adesão dos Gestores respondentes dos questionários. Foram respondidos 55 questionários dos 197 Institutos pesquisados. Perfazendo um índice de $28,4 \%$ de respostas.

Também é bom lembrar que todo o processo da pesquisa se deu de forma online, realizado pelo envio do link de acesso aos e-mail's dos gestores, e, após uma semana, reenviado para àqueles que não haviam respondido, numa tentativa de aumentar esse índice de respostas. Estes email's dos gestores foram obtidos acessando os sites dos referidos Institutos ou contactando-os via telefone.

\subsection{Modelo Conceitual Teórico}

O modelo descrito na Figura 3 representa o design central desta pesquisa. Embora a maior parte das variáveis inseridas neste trabalho tenha sido fundamentada, basicamente, em 
uma base teórico-epistemológica própria para explicação do desempenho em empresas privadas, esperou-se que estas variáveis também fossem determinantes do desempenho no setor Público. O mesmo ocorreu com as outras variáveis inseridas pelo pesquisador por serem julgadas relevantes ao contexto.

\section{Figura 3: Modelo Conceitual Teórico}

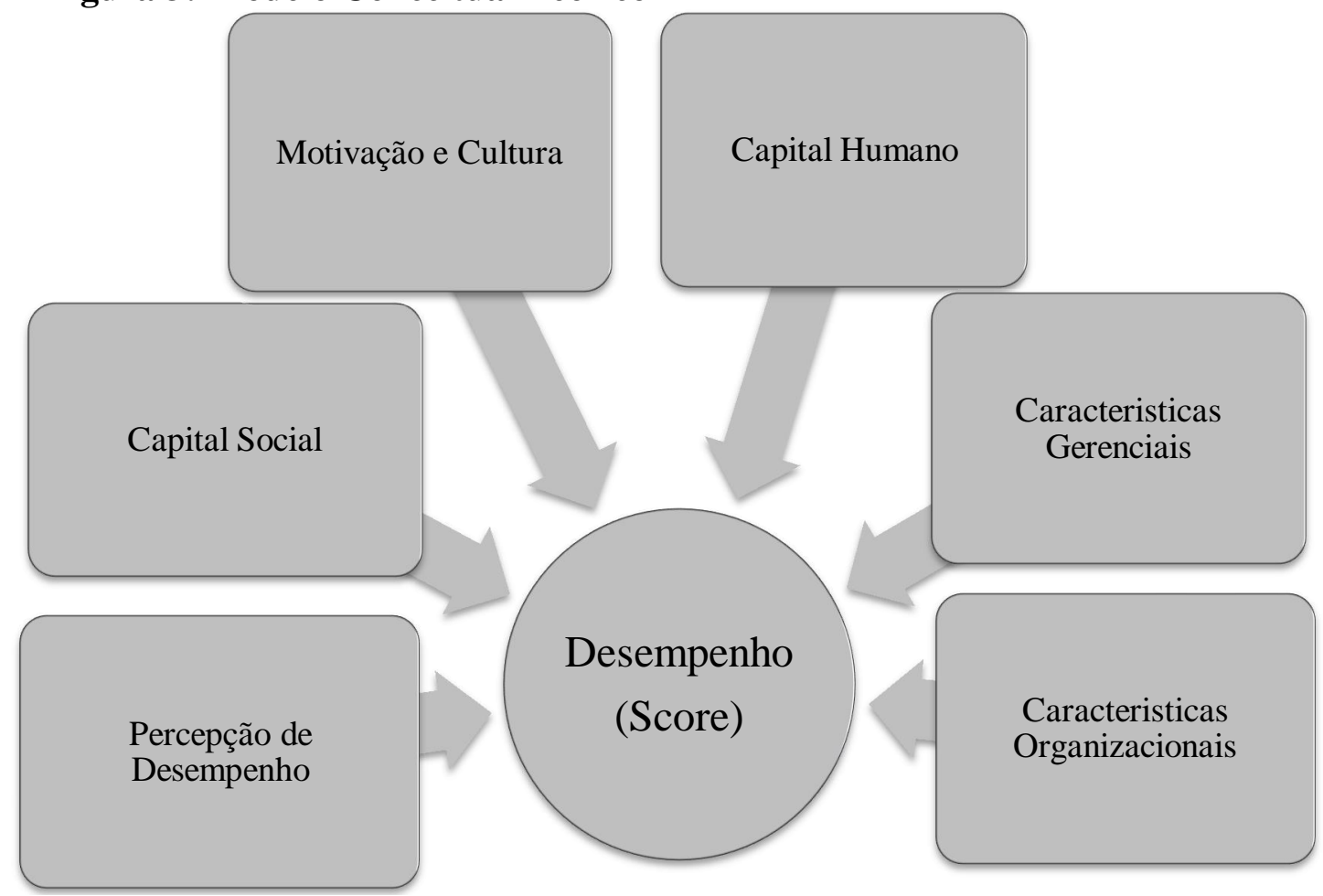

Fonte: Elaborado pelo autor.

\subsection{Definição das variáveis}

\subsubsection{Variável explicada: desempenho Investimento/Orçamento}

A variável desempenho foi determinada por uma escala métrica, e refere-se à gestão operacional e orçamentária no âmbito dos IF's, ao qual foi definido, neste trabalho, como determinante da qualidade do gasto público, ou, em outras palavras, foi determinada pela relação da taxa de Investimento/dispêndio total. É a partir desta variável, a qual funcionou 
como Proxy de desempenho, que foi identificado e ranqueado o desempenho das Instituições quanto aos pressupostos orçamentário.

Para obtenção destes valores, foi obtida a média aritmética simples dos dados dos gastos dos campi por rubrica de despesa entre os anos de 2012, 2013 e 2014, agrupando os em custeio, de um lado, dos gastos em investimento, do outro (distinção por categoria econômica3 Custeio e 4 investimento).

A utilização da média aritmética simples teve o intuito de identificar com mais precisão o desempenho das unidades. Relativizando àquelas que, por um motivo ou outro, obtiveram bons resultados num determinado ano, mas não configurando um padrão de desempenho.

Também, é bom informar que todos os dados foram obtidos a partir do Portal da Transparência, contudo, alguns dos campi pesquisados não dispunham de dados no referido sitio, fato que o excluiu da pesquisa. Restando na amostra um total de 197 campi efetivamente analisados.

Quanto à estratégia de análise desses dados, primeiramente foi feito um ranqueamento do comportamento orçamentário desses campi, classificando os campi em ordem crescente de acordo com a porcentagem de despesa em investimento despendida. Em seguida, foi feita uma análise estatística descritiva desses dados, no intuito de desvelar padrões de comportamento, utilizando-se, dentre outros, de histogramas e gráficos de dispersão. Adicionalmente, também foi feito uma identificação dos campi que obtiveram taxas de investimento muito elevadas, contrapostas com campi que obtiveram taxas de investimento muito baixas.

\subsubsection{Variáveis Explicativas}

Para explicar o desempenho dos Institutos (variável dependente), os indicadores foram testados, tanto individualmente, por meio da análise de Regressão Simples, quanto no modelo geral, por uma análise de Regressão Múltipla. Assim, esboçam-se neste tópico os fatores 
(constructos) e os respectivos indicadores (variáveis independentes) com seus pressupostos conceituais e sinais esperados em relação a variável dependente.

No Quadro 01 estão discriminados os pressupostos conceituais do ñCapital Humanoò juntamente com os sinais esperados.

Quadro 1: Variáveis explicativas, sinal esperado e pressupostos conceituais de ñ Capital Humanoò

\begin{tabular}{|c|c|c|c|}
\hline Constructo & $\begin{array}{c}\text { Indicadores / } \\
\text { Var. explicativas }\end{array}$ & Sinal & Pressupostos conceituais \\
\hline & Escolaridade & + & $\begin{array}{l}\text { Quanto maior a escolaridade do gestor, } \\
\text { melhor o desempenho da instituição. }\end{array}$ \\
\hline & $\begin{array}{l}\text { Experiência } \\
\text { profissional }\end{array}$ & + & $\begin{array}{l}\text { A experiência anterior está associado } \\
\text { positivamente ao melhor desempenho } \\
\text { profissional. }\end{array}$ \\
\hline & Liderança & + & $\begin{array}{l}\text { Gestores com habilidade de liderança tem } \\
\text { melhor desempenho operacional. }\end{array}$ \\
\hline & Experiência Gerencial & + & $\begin{array}{l}\text { A Experiência Gerencial está associada } \\
\text { positivamente ao desempenho. }\end{array}$ \\
\hline
\end{tabular}

Fonte: Elaborado pelo autor.

Na Tabela 01 estão descritos os indicadores que foram utilizados para operacionalizar os testes deste constructo.

Tabela 1: Caracterização operacional dos indicadores de ñCapital Humanoà

\begin{tabular}{lllc}
\hline Indicador & Descrição & Tipo & Escala \\
\hline Escol_CH & Escolaridade & Ordinal & 5 \\
ExperProf_CH & Experiência Profissional & Ordinal & 6 \\
ExperLider_CH & Liderança & Ordinal & 6 \\
ExperCarg_CH & Experiência no mesmo cargo & Ordinal & 5 \\
\hline
\end{tabular}

Fonte: Elaborado pelo autor.

No Quadro 02 estão descritas as variáveis explicativas, o sinal esperado e os pressupostos conceituais do ñCapital Socialò. Já na Tabela 02 estão descritos os indicadores utilizados para testar este constructo. 
Quadro 2: Variáveis explicativas, sinal esperado e pressupostos conceituais de ñCapital Socialà

\begin{tabular}{|c|c|c|c|}
\hline \multirow{2}{*}{ Constructo } & Indicadores / & Sinal & Pressupostos conceituais \\
\hline Var. explicativas & $\begin{array}{c}\text { Instituiços Públicas } \\
\text { Parceiras }\end{array}$ & + & $\begin{array}{c}\text { Quanto mais houver ajuda dos parceiros, } \\
\text { melhor o desempenho. }\end{array}$ \\
\cline { 2 - 4 } $\begin{array}{c}\text { II. Capital } \\
\text { Social }\end{array}$ & Consultoria & + & $\begin{array}{c}\text { Quanto mais bem orientada for a tomada a } \\
\text { decisão do gestor, melhor o desempenho final. }\end{array}$ \\
\cline { 2 - 4 } & Cooperação externa & + & $\begin{array}{c}\text { Reitoria, fornecedores, entre outros, podem } \\
\text { cooperar e ajudar a instituição no } \\
\text { desenvolvimento de suas competências. } \\
\text { Resultando em desempenho final. }\end{array}$ \\
\hline
\end{tabular}

Fonte: Elaborado pelo autor.

Tabela 2: Caracterização operacional dos indicadores de ñCapital Socialò

\begin{tabular}{lllc}
\hline Indicador & Descrição & Tipo & Escala \\
\hline CoopExt_CS & Cooperação externa & Likert & 5 \\
Consult_CS & Consultoria & Nominal & 2 \\
InstPúbParc_CS & Instituições Públicas Parceiras & Likert & 5 \\
CoopExt2_CS & Cooperação externa & Likert & 5 \\
\hline
\end{tabular}

Fonte: Elaborado pelo autor.

No Quadro 03 estão explicitados os pressupostos conceituais e as influências esperadas para o constructo ñCaracterísticas Gerenciaisò.

Quadro 3: Variáveis explicativas, sinal esperado e pressupostos conceituais de ñCaracterísticas Gerenciaisò

\begin{tabular}{|c|c|c|c|}
\hline \multirow{2}{*}{ Constructo } & $\begin{array}{c}\text { Indicadores } \\
\text { Var. } \\
\text { explicativas }\end{array}$ & Sinal & Pressupostos conceituais \\
\hline \multirow{2}{*}{$\begin{array}{c}\text { III. Características } \\
\text { política }\end{array}$} & - & $\begin{array}{c}\text { Quanto maior a ingerência por motivos políticos, } \\
\text { menor o desempenho da Instituição. }\end{array}$ \\
\cline { 2 - 4 } & Planejamento & + & $\begin{array}{c}\text { Quanto melhor for planejada a ação pública, maior } \\
\text { o sucesso da ação e menor desperdício. }\end{array}$ \\
\cline { 2 - 4 } & Burocracia & - & $\begin{array}{c}\text { Organizaçôes excessivamente burocráticas perdem } \\
\text { a visão para a necessidade da sociedade. Assim, } \\
\text { dificultam as ações ao voltarem-se para si mesmas. }\end{array}$ \\
\cline { 2 - 4 } & Reconhecimento & + & $\begin{array}{c}\text { Um incentivador do desempenho é o } \\
\text { reconhecimento do trabalho dos colaboradores. }\end{array}$ \\
\hline
\end{tabular}

Fonte: Elaborado pelo autor.

Neste constructo foram explorados quatro aspectos, apresentados na Tabelo 03. 
Tabela 3: Caracterização operacional dos indicadores de ñCaracterísticas Gerenciaisò

\begin{tabular}{lllc}
\hline Indicador & Descrição & Tipo & Escala \\
\hline IngerPol_CG & Ingerência política & Likert & 5 \\
Planej_CG & Planejamento & Likert & 5 \\
Buroc_CG & Burocracia & Likert & 5 \\
Recon_CG & Reconhecimento & Likert & 5 \\
\hline
\end{tabular}

Fonte: Elaborado pelo autor.

No Quadro 04 estão explicitados os pressupostos conceituais do constructo ñMotivação e Culturaòe as influências esperadas.

Quadro 4: Variáveis explicativas, sinal esperado e pressupostos conceituais de Motivação e Cultura.

\begin{tabular}{|c|c|c|c|c|}
\hline \multicolumn{2}{|c|}{ Constructo } & Indicadores & Sinal & Pressupostos conceituais \\
\hline \multirow[t]{3}{*}{ IV. } & \multirow{3}{*}{$\begin{array}{l}\text { Motivação e } \\
\text { Cultura }\end{array}$} & Motivação & + & $\begin{array}{l}\text { O pressuposto é de que quanto maior a } \\
\text { motivação da equipe, maior o } \\
\text { desempenho. }\end{array}$ \\
\hline & & Sabotagem & - & $\begin{array}{c}\text { Colaboradores com perfil de sabotagem } \\
\text { subtraem resultados. }\end{array}$ \\
\hline & & Comprometimento & + & $\begin{array}{l}\text { O nível de comprometimento afeta } \\
\text { positivamente o desempenho. }\end{array}$ \\
\hline
\end{tabular}

Fonte: Elaborado pelo autor.

Os testes deste constructo foram conduzidos utilizando os indicadores apresentados na

Tabela 04.

Tabela 4: Caracterização operacional dos indicadores de ñ́Motivação e Culturaò

\begin{tabular}{lllc}
\hline Indicador & Descrição & Tipo & Escala \\
\hline MotivEquip_MC & Motivação & Likert & 5 \\
Sabot_MC & Sabotagem & Likert & 5 \\
MotFunç_MC & Motivação & Likert & 5 \\
Comprom_MC & Comprometimento & Likert & 5 \\
\hline
\end{tabular}

Fonte: Elaborado pelo autor.

No Quadro 5 estão os indicadores apresentados e os sinais esperados para o constructo ñPercepção de Desempenhoò. 
Quadro 5: Variáveis explicativas, sinal esperado e pressupostos conceituais de ñPercepção de Desempenhoà

\begin{tabular}{|c|c|c|c|}
\hline Constructo & $\begin{array}{c}\text { Indicadores } \\
\text { Var. } \\
\text { explicativas }\end{array}$ & Sinal & Pressupostos conceituais \\
\hline \multirow{2}{*}{$\begin{array}{c}\text { V. Percepção de } \\
\text { Desempenho }\end{array}$} & Desperdício & - & $\begin{array}{c}\text { Quanto maior o desperdício na Instituição, menor a } \\
\text { aproximação do desempenho, ou, em outras } \\
\text { palavras, da qualidade do gasto público. }\end{array}$ \\
\cline { 2 - 4 } & Desempenho & + & $\begin{array}{c}\text { Neste indicador, busca-se descobrir se a ideia } \\
\text { principal deste trabalho é compartilhada pelos } \\
\text { gestores. Assim, quanto mais houver consenso } \\
\text { deste conceito, de qualidade do gasto público, mais } \\
\text { estes gestores irão persegui-lo. }\end{array}$ \\
\cline { 2 - 4 } & $\begin{array}{c}\text { Produtividade } \\
\text { do gasto }\end{array}$ & + & $\begin{array}{c}\text { Da mesma forma que o indicador anterior, a } \\
\text { medida que se acredita que o gasto em } \\
\text { investimento é melhor que o gasto em custeio. } \\
\text { Busca-o. }\end{array}$ \\
\hline
\end{tabular}

Fonte: Elaborado pelo autor.

Na Tabela 05 estão descritos os indicadores que foram utilizados para compor este constructo.

Tabela 5: Caracterização operacional dos indicadores de ñ̃ercepção de Desempenhoò

\begin{tabular}{lllc}
\hline Indicador & Descrição & Tipo & Escala \\
\hline Desperd_PD & Desperdício & Likert & 5 \\
Desempe_PD & Desempenho & Nominal & 2 \\
Produt_PD & Produtividade & Nominal & 2 \\
Desperd2_PD & Desperdício & Likert & 5 \\
\hline
\end{tabular}

Fonte: Elaborado pelo autor.

No próximo constructo, ñCaracterísticas Organizacionaisò, exploraram-se quatro indicadores, os quais estão descritos no Quadro 06, juntamente com os pressupostos conceituais e as influências esperadas. 
Quadro 6: Variáveis explicativas, sinal esperado e pressupostos conceituais de ñCaracterísticas Organizacionaisò

\begin{tabular}{|c|c|c|c|}
\hline Constructo & $\begin{array}{c}\text { Indicadores / } \\
\text { Var. explicativas }\end{array}$ & Sinal & Pressupostos conceituais \\
\hline \multirow{4}{*}{$\begin{array}{l}\text { VI. Características } \\
\text { Organizacionais }\end{array}$} & Qualidade do Staff & + & $\begin{array}{l}\text { Quanto melhor for a qualidade do staff } \\
\text { da organização, melhor será seu } \\
\text { desempenho. }\end{array}$ \\
\hline & $\begin{array}{c}\text { Experiência } \\
\text { ocupacional da equipe }\end{array}$ & + & $\begin{array}{l}\text { A experiência anterior está associado } \\
\text { positivamente a melhor desempenho } \\
\text { profissional. }\end{array}$ \\
\hline & Capacitação da equipe & + & $\begin{array}{c}\text { A aquisição de conhecimento eleva o } \\
\text { desempenho operacional. }\end{array}$ \\
\hline & Sinergia & + & $\begin{array}{c}\text { Quanto melhor estiver a sinergia da } \\
\text { equipe, melhor o desempenho. }\end{array}$ \\
\hline
\end{tabular}

Fonte: Elaborado pelo autor.

Na Tabela 06 estão apresentados os indicadores operacionais utilizados para testar os impactos sobre o desempenho.

Tabela 6: Caracterização operacional dos indicadores de ñCaracterísticas Organizacionaisà

\begin{tabular}{lllc}
\hline Indicador & Descrição & Tipo & Escala \\
\hline ServOrça_CO & Qualidade do staff & Likert & 5 \\
ExperProf_CO & Experiência ocupacional & Likert & 5 \\
Capacequip_CO & Capacitação da equipe & Ordinal & 4 \\
Sinerg_CO & Sinergia & Likert & 5 \\
\hline
\end{tabular}

Fonte: Elaborado pelo autor.

\subsection{Pré-testes de aplicação dos questionários}

Logo após a elaboração do questionário, e antes da aplicação na população, o instrumento passou por um processo de validação semântica, em que se buscou averiguar a linguagem utilizada no instrumento, evitando incompreensões pelos respondentes e redundando em menos vieses na interpretação das assertivas.

Nesta etapa foram selecionados dois grupos de indivíduos para atuarem. O primeiro, composto por três especialistas da área de Ensino; o segundo, por seis possíveis respondentes, ou seja, indivíduos com características semelhantes aos das amostras a serem utilizadas. Tanto 
os especialistas quanto os possíveis respondentes foram selecionados devido à facilidade de acesso a estas pessoas.

Entre os aspectos observados pelos grupos, em primeiro lugar, foi questionado o número de afirmações do questionário, considerado muito extenso; para o que foi explicado que se tratava de um questionário em que se buscava algum fator determinante do desempenho, havendo necessidade de sondar diversas possibilidades.

Outras observações se deram quanto a alteração de algumas estruturas frasais ou alteração de certas palavras por sinônimos, no intuito de deixar as sentenças mais acessíveis. Assim, após realizada as mudanças sugeridas, o instrumento foi submetido a amostra.

\subsection{Procedimento para coleta dos dados}

A coleta dos dados se deu de duas formas distintas. A primeira, para obtenção das variáveis explicadas, ou seja, o desempenho das unidades. Neste caso colheram-se informações a partir do site do Portal da Transparência, em que foram retiradas todas as despesas realizadas pelos campi no período de 2012, 2013 e 2014, detalhadamente por rubrica de gasto. Porém, como o critério de desempenho deste trabalho limitava-se a análise da quantidade de recurso destinado a investimento em relação ao gasto total da unidade, apenas ateve-se a distinção por categoria econômica (3- Custeio e 4- investimento).

A segunda forma de coleta de dados foi operacionalizada por meio de questionários com questões estruturadas que foram respondidos pelos Diretores Gerais e/ou Diretores Administrativos e/ou cargos equivalentes, de acordo com o organograma da unidade. Esta opção se dá em virtude de serem eles (gestores públicos) que respondem legalmente pelas práticas de gestão da instituição, além de serem eles que possuem autoridade e responsabilidade para direcionar ou autorizar as compras, os orçamentos etc.. 
A forma de acesso dos respondentes foi feita via e-mail, em que foi disponibilizado o link do questionário, o qual estava todo de forma online. Em um segundo momento foram reenviados os emails àqueles que não haviam respondido ao questionário.

Por questões éticas e para um melhor desenvolvimento da pesquisa, os respondentes se mantiveram anônimos, assim como os cargos que possuíam, pois a nominação dessas permitiria a identificação dos respondentes.

\subsection{Limitações do Estudo}

A validade estatística da pesquisa pode ser comprometida, pois a taxa de não-respostas foi alta, bem como se houve vieses nas respostas dos gestores, visto está sendo realizada por questionários fechados auto-administrados.

Também, é bom registrar, que não houve visitas in loco, nas Instituições pesquisadas, tendo como informação as fontes secundarias provenientes do Portal da Transparência, podendo, assim, sofrer por falta de dados ou inexatidão. 


\section{RESULTADOS E DISCUSSÕES}

\subsection{Descrição da Amostra}

\subsubsection{Descrição dos indicadores de desempenho}

O levantamento realizado no Portal da Transparência permitiu ranquear os campi de acordo com a quantidade de recurso despendido em investimento, como se observa no gráfico (Apêndice C).

A fim de identificar discrepâncias no comportamento dos gastos da Rede Federal de Educação Profissional ocorridas entre os anos que compuseram a serie histórica analisada, foi feito um histograma com o comportamento da porcentagem de investimento de cada ano e com a média geral. Assim, obtiveram-se os histogramas abaixo:

Figura 4: Histogramas do comportamento das taxas de investimento 2012, 2013, 2014 e Média.
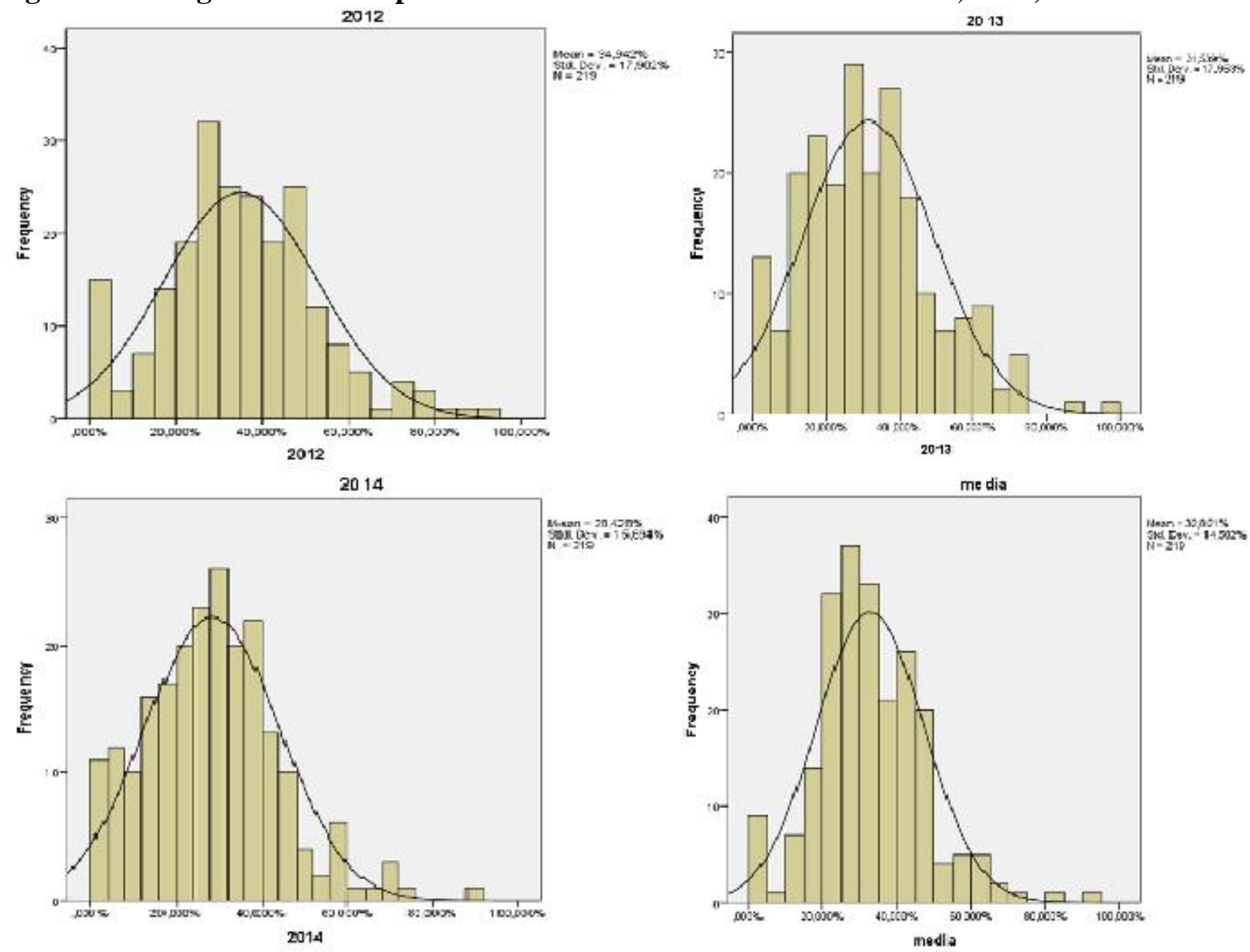

Fonte: Elaborado pelo Autor. 
Note-se que as trajetórias dos histogramas se assemelham muito, o que denota que não houve grandes variações no comportamento dos gastos da Rede de um ano para o outro. Havendo certa homogeneidade nos dados trabalhados. Mesmo sendo uma amostra com um quantitativo de dados significativo, o que já indicaria haver normalidade nesse comportamento, ainda assim, estes foram submetidos aos testes de normalidade de Kolmogorov-Smirnov e de Shapiro-Wilk. Como esperado, os resultados apontaram para uma taxa de normalidade superior a $95 \%$.

Adicionalmente, para subsidiar a análise do comportamento dos gastos públicos realizados pelos campi da Rede Federal de Educação Profissional, bem como de seus respectivos componentes, a Tabela 07 apresenta um conjunto de estatísticas descritivas, para fundamentar um diagnostico do perfil do gasto.

Tabela 7: Estatística Descritiva do comportamento do Gasto em Investimento na Rede Federal de Educação

\begin{tabular}{lcccc}
\hline Estatística & $\mathbf{2 0 1 2}$ & $\mathbf{2 0 1 3}$ & $\mathbf{2 0 1 4}$ & Média \\
\hline Média & $34,94 \%$ & $31,53 \%$ & $28,42 \%$ & $32,82 \%$ \\
Desvio Padrão & $17,90 \%$ & $17,95 \%$ & $15,69 \%$ & $14,50 \%$ \\
Variância & 320,49 & 322,30 & 246,29 & 210,31 \\
Mínimo & $0,0 \%$ & $0,0 \%$ & $0,0 \%$ & $0,0 \%$ \\
Máximo & $92,61 \%$ & $95,82 \%$ & $89,54 \%$ & $92,90 \%$ \\
\hline
\end{tabular}

Fonte: Elaboração própria.

As estatísticas descritivas expressas nessa Tabela 07 apresentam algumas informações relevantes. A princípio, note-se que a média dos gastos em investimentos nos três anos consecutivos são próximas uma das outras. Em torno de $32 \%$. Sendo considerado um quantitativo relativamente alto se comparado com os gastos em investimento do Governo Federal, que foram menores que 1\% nos anos de 2012, 2013 e 2014, respectivamente (BRASIL, 2015). Fato que ratifica o discurso do Governo de que o ensino TécnicoProfissionalizante constitui estratégia de crescimento econômico do Governo e, por isso, está em franca expansão. 
Outro ponto relevante diz respeito aos desvios padrão encontrado, que podem ser considerados baixos, em torno de $15 \%$. O que indica que os campi, no geral, tendem a despender taxas de investimentos próximas uns dos outros e em torno da média. Havendo pouca dispersão nesse comportamento. Fato também comprovado pela análise visual dos histogramas.

Esse índice pode, por suposição, ser explicado em razão de esses campi terem compartilhado da mesma história recente, desde a criação até o funcionamento regular, o que poderia propiciar um modo de gerir o orçamento de maneira similar, além de fazerem parte de uma Rede, o qual, por si só, determina padrões específicos de comportamento.

O mesmo comportamento foi observado com os valores obtidos na variância, indicando "o quão longe", em geral, os seus valores se encontram do valor esperado. Quanto os valores mínimos e máximos encontrados, estes demonstram que, enquanto alguns campi, sequer gastaram em investimento nesses 03 anos, outros despenderam cerca de $90 \%$ dos gastos com destinação a rubrica investimento, nesse mesmo período. 
Figura 5: Gráfico Bloxpot do comportamento do Investimento.
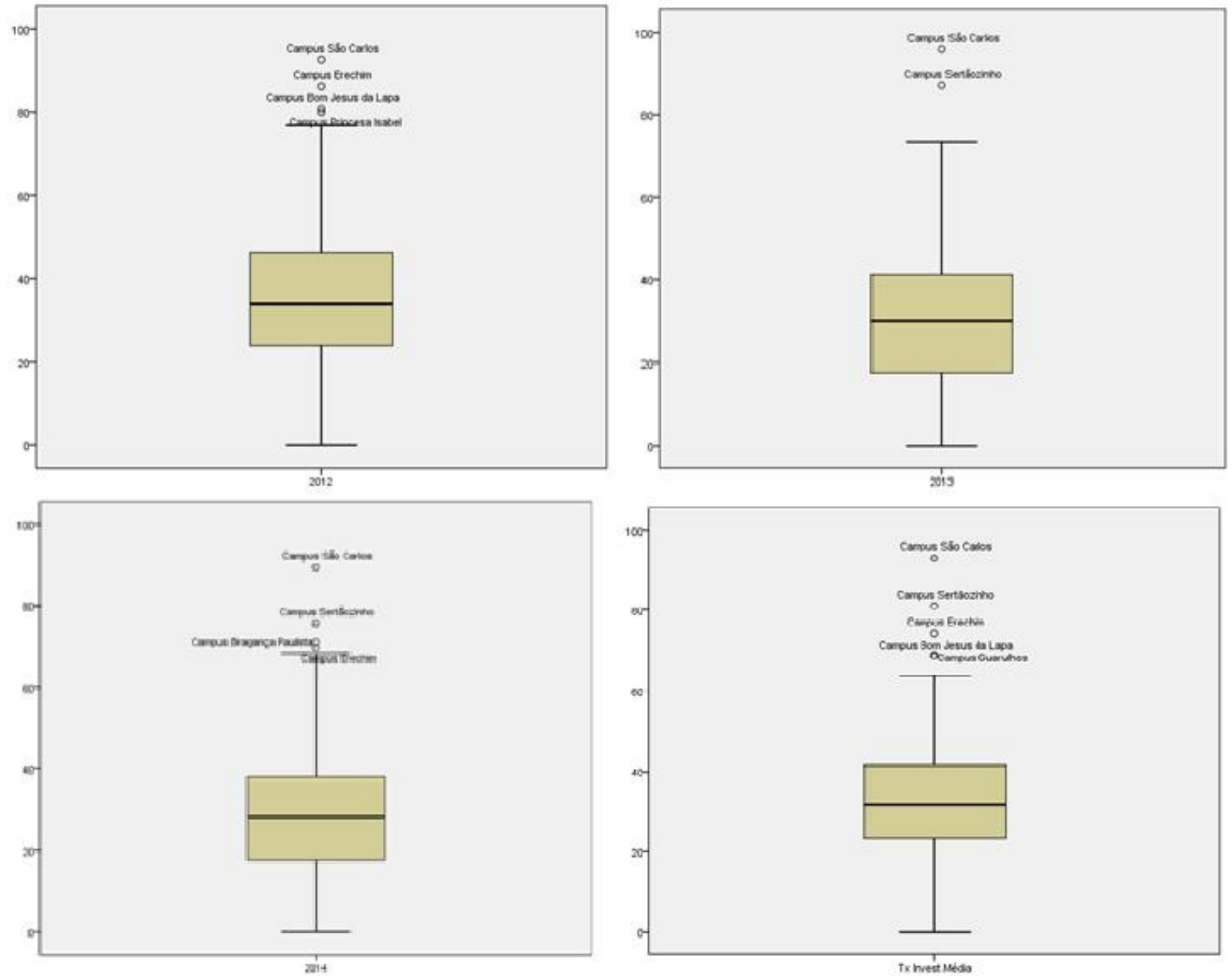

Fonte: Elaboração própria.

Ao analisar o gráfico blox plot (Figura 5), note-se que poucos campi comportaram-se diferentemente dos demais, considerados, por isso, out liers da pesquisa. Esses campi obtiveram médias de gasto em investimento muito acima do normal, chegando a $92 \%$ de destinação a investimento. Assim, desta forma elaborou-se a tabela 8: 
Tabela 8: Identificação dos casos polares.

\begin{tabular}{|c|c|c|c|c|}
\hline & 2012 & 2013 & 2014 & Geral \\
\hline \multirow{5}{*}{$\begin{array}{l}\text { Campi com alta } \\
\text { taxa de } \\
\text { investimento }\end{array}$} & $\begin{array}{l}\text { Campus São } \\
\text { Carlos (92,61\%) }\end{array}$ & $\begin{array}{l}\text { Campus São } \\
\text { Carlos (95,82\%) }\end{array}$ & $\begin{array}{l}\text { Campus São } \\
\text { Carlos (89,54\%) }\end{array}$ & $\begin{array}{l}\text { Campus São } \\
\text { Carlos (92,9\%) }\end{array}$ \\
\hline & $\begin{array}{c}\text { Campus Erechim } \\
(86,22)\end{array}$ & $\begin{array}{c}\text { Campus } \\
\text { Sertãozinho } \\
(87,09 \%) \\
\end{array}$ & $\begin{array}{c}\text { Campus } \\
\text { Sertãozinho } \\
(75,73 \%) \\
\end{array}$ & $\begin{array}{c}\text { Campus } \\
\text { Sertãozinho } \\
(91,0 \%) \\
\end{array}$ \\
\hline & $\begin{array}{c}\text { Campus Bom } \\
\text { Jesus da Lapa } \\
(80,22 \%) \\
\end{array}$ & $\begin{array}{c}\text { Campus Guarulhos } \\
(73,55 \%)\end{array}$ & $\begin{array}{c}\text { Campus } \\
\text { Bragança } \\
\text { Paulista }(71,21 \%) \\
\end{array}$ & $\begin{array}{l}\text { Campus } \\
\text { Erechim } \\
(74,35 \%) \\
\end{array}$ \\
\hline & $\begin{array}{l}\text { Campus Princesa } \\
\text { Isabel }(79,93 \%\end{array}$ & $\begin{array}{c}\text { Campus Cabedelo } \\
(73,09 \%)\end{array}$ & $\begin{array}{c}\text { Campus Erechim } \\
(69,69 \%)\end{array}$ & $\begin{array}{l}\text { Campus } \\
\text { Guarulhos } \\
(68,86 \%)\end{array}$ \\
\hline & $\begin{array}{c}\text { Campus Maceió } \\
(76,90 \%)\end{array}$ & $\begin{array}{c}\text { Campus Bom } \\
\text { Jesus da Lapa } \\
(71,66 \%)\end{array}$ & $\begin{array}{l}\text { Campus } \\
\text { Farroupilha } \\
(68,27 \%) \\
\end{array}$ & $\begin{array}{c}\text { Campus Bom } \\
\text { Jesus da Lapa } \\
(68,49 \%)\end{array}$ \\
\hline \multirow{5}{*}{$\begin{array}{l}\text { Campi com baixa } \\
\text { taxa de } \\
\text { investimento }\end{array}$} & $\begin{array}{c}\text { Campus Macaé } \\
(0 \%)\end{array}$ & $\begin{array}{c}\text { Campus Macaé } \\
(0 \%)\end{array}$ & $\begin{array}{l}\text { Campus Macaé } \\
(0 \%)\end{array}$ & $\begin{array}{c}\text { Campus Macaé } \\
(0 \%)\end{array}$ \\
\hline & $\begin{array}{c}\text { Campus Itaperuna } \\
(0 \%)\end{array}$ & $\begin{array}{c}\text { Campus Itaperuna } \\
(0 \%)\end{array}$ & $\begin{array}{c}\text { Campus } \\
\text { Itaperuna }(0 \%)\end{array}$ & $\begin{array}{c}\text { Campus } \\
\text { Itaperuna }(0 \%)\end{array}$ \\
\hline & $\begin{array}{c}\text { Campus Cabo Frio } \\
(0 \%)\end{array}$ & $\begin{array}{c}\text { Campus Campos } \\
(0 \%)\end{array}$ & $\begin{array}{c}\text { Campus Campos } \\
(0 \%)\end{array}$ & $\begin{array}{l}\text { Campus } \\
\text { Campos } \\
(0,08 \%) \\
\end{array}$ \\
\hline & $\begin{array}{c}\text { Campus Bom } \\
\text { Jesus do } \\
\text { Itabapoana }(0 \%)\end{array}$ & $\begin{array}{c}\text { Campus Cabo Frio } \\
(0 \%)\end{array}$ & $\begin{array}{l}\text { Campus Cabo } \\
\text { Frio }(0,38 \%)\end{array}$ & $\begin{array}{c}\text { Campus Cabo } \\
\text { Frio }(0,16 \%)\end{array}$ \\
\hline & $\begin{array}{c}\text { Campus Guarus } \\
(0 \%)\end{array}$ & $\begin{array}{c}\text { Campus } \\
\text { Paranagua (0\%) }\end{array}$ & $\begin{array}{l}\text { Campus Piripiri } \\
(0,43 \%)\end{array}$ & $\begin{array}{l}\text { Campus } \\
\text { Formiga } \\
(1,18 \%)\end{array}$ \\
\hline
\end{tabular}

Fonte: Elaborado pelo autor.

Observa-se que, de forma sucinta, os campi que compõe o Instituto Federal de São Paulo (IFSP) obtiveram taxas mais altas de gastos em investimento, enquanto os campi que fazem parte do Instituto Federal Fluminense (IFF) obtiveram resultados opostos.

\subsubsection{Descrição dos indicadores de Capital Humano}

Esse constructo procurou identificar indicadores relativos a experiências, vivências e habilidades adquiridas pelo Gestor que possa permitir melhoria do seu desempenho profissional, e, consequentemente, do desempenho de sua instituição.

Assim, compôs este constructo:

a) Educação/Escolaridade

b) Experiência Profissional 
c) Experiência em Cargos de Liderança

d) Experiência no Cargo

Na Tabela 09 observa-se o Perfil de escolaridade dos Gestores, sendo que a maioria $(54,6 \%)$ possui especialização, $27,2 \%$ possui Mestrado e $9,1 \%$ possui como escolaridade o Doutorado e o Ensino Superior. Nenhum Gestor possuía apenas o ensino Médio.

Tabela 9: Perfil Escolaridade

\begin{tabular}{lrr}
\hline Escolaridade & \multicolumn{1}{c}{ F } & \multicolumn{1}{c}{$\%$} \\
\hline Ensino Médio & 0 & 0 \\
Ensino Superior & 5 & 9,1 \\
Especialização & 30 & 54,6 \\
Mestrado & 15 & 27,2 \\
Doutorado & 5 & 9,1 \\
\hline Total & 55 & 100,0 \\
\hline \hline$\%$
\end{tabular}

$\mathrm{Na}$ amostra, 25,5\% responderam nunca ter exercido atividade profissional em empresas privadas antes de ser Diretor, 36,4\% informaram possuir de 1 a 5 anos de experiência, enquanto o restante ficou distribuído entre as variáveis remanentes. Entretanto, ganha destaque que mais da metade dos Gestores (67,3\%) alegaram possuir entre 01 e 20 anos de experiência em área privada anterior a nomeação do cargo que ocupa (Tabela 10).

Tabela 10: Experiência Profissional

\begin{tabular}{llcrc}
\hline Indicador & $\begin{array}{l}\text { Experiência } \\
\text { profissional }\end{array}$ & F & \% & \% ac \\
\hline Antes de ser Diretor(a), & Não & 14 & 25,5 & 25,5 \\
você já havia trabalhado & Menos de 1 ano & 2 & 3,6 & 29,1 \\
em empresas privadas & De 1 a 5 anos & 20 & 36,4 & 65,5 \\
como empregado? & De 6 a 10 anos & 8 & 14,5 & 80,0 \\
& De 11 a 20 anos & 9 & 16,4 & 96,4 \\
& Mais de 20 anos & 2 & 3,6 & 100 \\
\hline \hline Total & & 55 & 100,0 & - \\
\hline
\end{tabular}

Fonte: Elaboração própria. 
$\mathrm{Na}$ Tabela 11 fica demonstrado que 65,5\% dos respondentes alegaram ter possuído pessoas ou empregados sob seu comando entre 1 e 10 anos de sua vida profissional pregressa. Por outro lado, 14,5\% alegaram não o ter possuído. Entretanto, cotejando este indicador com o cargo/função que este Gestor possui, nota-se que enquanto 33\% dos Coordenadores de Adm. não possuíam experiência de liderança anterior, menos de $9 \%$ dos Diretores de Administração e menos de $19 \%$ dos Diretores Gerais não o possuíam.

Tabela 11: Experiência em Cargos de Liderança

\begin{tabular}{llccccc}
\hline Indicador & Liderança & $\begin{array}{c}\text { Diretor } \\
\text { Geral }\end{array}$ & $\begin{array}{c}\text { Diretor } \\
\text { de Adm. }\end{array}$ & $\begin{array}{c}\text { Coordenador } \\
\text { de Adm. }\end{array}$ & F & \% \\
\hline Antes de ser & Não & 2 & 3 & 3 & 8 & 14,5 \\
Diretor(a), você & Menos de 1 ano & 1 & 2 & 1 & 4 & 7,3 \\
ocupou cargo/função & De 1 a 2 anos & 1 & 6 & 2 & 9 & 16,4 \\
na qual possuía & De 3 a 5 anos & 2 & 14 & 2 & 18 & 32,7 \\
pessoas/empregados & De 6 a 10 anos & 3 & 6 & 1 & 9 & 16,4 \\
sob seu comando? & Mais de 10 anos & 2 & 5 & 0 & 7 & 12,7 \\
\hline \hline Total & & 11 & 35 & 9 & 55 & 100,0 \\
\hline
\end{tabular}

Fonte: Elaboração própria.

Por fim, o último indicador sondado neste constructo foi da Experiência que o Gestor possuía no Cargo que ocupa, ao que foi respondido que $20 \%$ o ocupavam a menos de 1 ano, $36,4 \%$ de 1 a 3 anos, 25,5\% de 3 a 6 anos, $12,7 \%$ de 6 a 10 anos e apenas 5,5\% acima de 10 anos (Tabela 12).

Tabela 12: Experiência no Cargo

\begin{tabular}{llll}
\hline Indicador & $\begin{array}{l}\text { Experiência no } \\
\text { Cargo }\end{array}$ & F & \% \\
\hline Há quantos anos você & 1 ano ou menos & 11 & 20,0 \\
está no cargo em que & De 1 a 3 anos & 20 & 36,4 \\
ocupa nesse campus: & De 3 a 6 anos & 14 & 25,5 \\
& De 6 a 10 anos & 7 & 12,7 \\
& Acima de 10 anos & 3 & 5,5 \\
\hline \hline Total & 55 & 100,0 \\
\hline Fonte: Elaboração própria
\end{tabular}

Fonte: Elaboração própria. 


\subsubsection{Descrição dos indicadores de Capital Social}

Esse constructo procurou sondar possíveis recursos acessados, pelo Instituto, por meio de parcerias e redes de relacionamentos externas, tal quais Fornecedores, Reitoria e o próprio Governo, os quais poderiam, de alguma forma, contribuir para o desempenho. Ademais, inseriu-se neste constructo a contratação de Consultorias especializadas, como outra forma de acesso a recursos externos ao campus, os quais poderiam resultar em desempenho institucional.

Os indicadores de Capital Social utilizados neste constructo foram:
a) Instituições Públicas Parceiras
b) Consultorias
c) Cooperação externa

$\mathrm{Na}$ Tabela 13 nota-se que, neste indicador, os Gestores julgaram haver mais contribuição que nos indicadores anteriores deste constructo, 41,8\% afirmaram ter uma grande contribuição ao desenvolvimento do campus por parte dos Fornecedores, 40\% informaram haver uma contribuição mediana, 12,7\% afirmou existir pouca contribuição, 3,6\% afirmou existir muito pouca contribuição e $1,8 \%$ afirmou existir uma contribuição muito grande.

Tabela 13: Contribuição dos Fornecedores

\begin{tabular}{llll}
\hline Indicador & $\begin{array}{l}\text { Contribuição dos } \\
\text { Fornecedores }\end{array}$ & F & \% \\
\hline Qual a intensidade de & Muito pouco & 2 & 3,6 \\
contribuição ao & Pouco & 7 & 12,7 \\
desenvolvimento do seu & Médio & 22 & 40,0 \\
campus promovido pelos & Grande & 23 & 41,8 \\
Fornecedores? & Muito Grande & 1 & 1,8 \\
\hline \hline Total & & 55 & 100,0 \\
\hline
\end{tabular}

Fonte: Elaboração própria. 
O mesmo padrão de comportamento ocorreu no indicador de Suporte Governamental, em que $40 \%$ informaram haver um grande suporte por parte do Governo ao Instituto, 36,4\% um suporte mediano, $14,5 \%$ pouco suporte, $5,5 \%$ haver um suporte muito grande e $3,6 \%$ um suporte muito pequeno (Tabela 14).

Tabela 14: Suporte Governamental

\begin{tabular}{llll}
\hline Indicador & $\begin{array}{l}\text { Suporte } \\
\text { Governamental }\end{array}$ & F & \% \\
\hline Como você avalia, no & Muito pouco & 2 & 3,6 \\
geral, o suporte & Pouco & 8 & 14,5 \\
Governamental? & Médio & 20 & 36,4 \\
& Grande & 22 & 40,0 \\
& Muito Grande & 3 & 5,5 \\
\hline \hline Total & & 55 & 100,0 \\
\hline
\end{tabular}

Fonte: Elaboração própria.

A Tabela 15 explicita o indicador Suporte da Reitoria, indicador este em que os Gestores pesquisados afirmaram existir a maior contribuição ao desenvolvimento de seu campus, 43,6\% afirmaram ser grande o suporte oferecido pela Reitoria ao desenvolvimento de seu campus, 21,8\% ser mediano, 14,5\% um suporte pequeno, $14,5 \%$ um suporte muito grande e 5,5\% um suporte muito pequeno.

Tabela 15: Suporte da Reitoria

\begin{tabular}{lcll}
\hline Indicador & $\begin{array}{l}\text { Contribuição da } \\
\text { Reitoria }\end{array}$ & F & $\%$ \\
\hline Como você avalia, no & Muito pouco & 3 & 5,5 \\
geral, o suporte de sua & Pouco & 8 & 14,5 \\
Reitoria? & Médio & 12 & 21,8 \\
& Grande & 24 & 43,6 \\
& Muito Grande & 8 & 14,5 \\
\hline \hline Total & & 55 & 100,0 \\
\hline Fonte: Elaboração própria. & & &
\end{tabular}

Por fim, buscou-se conhecer quais campi haviam contratado Consultoria Especializada externa, assim, a grande maioria (83,3\%) alegou não ter feito este tipo de contratação, outros 16,7\% informaram já terem utilizado deste recurso (Tabela 16). 
Tabela 16: Utilização de Consultoria externa

\begin{tabular}{llll}
\hline Indicador & $\begin{array}{l}\text { Consultoria } \\
\text { Externa }\end{array}$ & F & \% \\
\hline Vocês já se utilizaram de consultoria & Não & 45 & 83,3 \\
especializada externa? & Sim & 9 & 16,7 \\
\hline \hline Total & & 54 & 100,0 \\
\hline Fonte: Elaboração própria. & & &
\end{tabular}

Cabe registrar que, neste indicador, um dos Gestores pesquisados não respondeu a pergunta.

\subsubsection{Descrição dos indicadores de Características Gerenciais}

As características Gerenciais consistem no estilo de gestão conduzido no campus, os quais são responsáveis por organizar, planejar, coordenar, executar e controlar. Determinando o padrão de eficiência final. Para construção desse constructo foram considerados os seguintes indicadores:

a) Ingerências Políticas

b) Planejamento

c) Excesso de Burocracia

d) Reconhecimento interno pelo bom desempenho dos colaboradores

No conjunto da amostra observou-se que $37 \%$ dos Gestores pesquisados afirmou haver muito pouca Ingerência Política, 22,5\% afirmou haver grande interferência política na gestão, $18,5 \%$ informou haver pouca ingerência e outros $18,5 \%$ haver uma ingerência mediana, apenas 3,7\% informou ser muito grande a interferência política dentro do campus (Tabela 17). Ressalta-se que, nesta questão, um dos participantes não a respondeu. 
Tabela 17: Existência de ingerência política

\begin{tabular}{llcc}
\hline Indicador & IngerPol_CG & F & \% \\
\hline Existe interferência ou & Muito pouco & 20 & 37,0 \\
ingerência de ações & Pouco & 10 & 18,5 \\
políticas sobre ações & Médio & 10 & 18,5 \\
técnicas? & Grande & 12 & 22,5 \\
& Muito Grande & 2 & 3,7 \\
\hline \hline Total & & 54 & 100,0 \\
\hline
\end{tabular}

Fonte: Elaboração própria.

Outro indicador que compôs este constructo refere-se ao grau de planejamento das compras e gastos do campus, observou-se que $67,3 \%$ dos respondentes posicionaram seus campi entre o grau ñgrandeò e ñmuito grandeò de planejamento, 27,3\% com planejamento mediano e 5,5\% com pouco planejamento. Ganha relevância que nenhum Gestor se posicionou como tendo um orçamento ñmuito poucoò planejado (Tabela 18).

Tabela 18: Grau de Planejamento Orçamentário

\begin{tabular}{llcc}
\hline Indicador & Planej_CG & F & $\%$ \\
\hline Qual o grau de & Muito pouco & 0 & 0 \\
planejamento sobre as & Pouco & 3 & 5,5 \\
compras e gastos & Médio & 15 & 27,3 \\
realizados no campus? & Grande & 28 & 50,9 \\
& Muito Grande & 9 & 16,4 \\
\hline \hline Total & & 54 & 100,0 \\
\hline Fonte: Elaboração própria. & & &
\end{tabular}

Na Tabela 19 buscou-se identificar os excessos burocráticos que, muitas vezes, entravam o funcionamento do serviço público, neste indicador 51,9\% alegaram ser ñgrandeò essa rigidez operacional, 25,9\% relatou a como ñmedianaò, $13 \%$ como ñmuito grandeòe 9,3\% como pouca. Nenhum Gestor se posicionou como ñmuito poucaò a rigidez administrativa provocada pelos excessos burocráticos. Ressalta-se que um dos pesquisados se absteve de responder este indicador. 
Tabela 19: Grau de Burocracia desnecessária interna

\begin{tabular}{llcc}
\hline Indicador & Buroc_CG & F & \% \\
\hline No geral, como você classificaria & Muito pouco & 0 & 0 \\
o excesso de rigidez operacional, & Pouco & 5 & 9,3 \\
inerente a burocracia do serviço & Médio & 14 & 25,9 \\
público, no seu campus? & Grande & 28 & 51,9 \\
& Muito Grande & 7 & 13 \\
\hline \hline Total & & 54 & 100,0 \\
\hline
\end{tabular}

Fonte: Elaboração própria.

Na Tabela 20, 41,8\% dos Gestores responderam que possuem ñgrandeò reconhecimento pelos bons Servidores, $23,6 \%$ que os reconhecem de forma mediana, 14,5\% que possuem ñmuito grandeò reconhecimento, apenas $18 \%$ acreditam que possuem ñpoucoò ou ñmuito poucoòreconhecimento dentro de seu campus.

Tabela 20: Grau de Reconhecimento dos bons Funcionários

\begin{tabular}{llcc}
\hline Indicador & Recon_CG & F & \% \\
\hline O instituto reconhece os & Muito pouco & 9 & 14,4 \\
bons servidores? & Pouco & 2 & 3,6 \\
& Médio & 13 & 23,6 \\
& Grande & 23 & 41,8 \\
& Muito Grande & 8 & 14,5 \\
\hline \hline Total & & 55 & 100,0 \\
\hline Fonte: Elaboração própria. & & &
\end{tabular}

\subsubsection{Descrição dos indicadores de Motivação e Cultura}

A ideia principal para elaboração desse constructo foi de identificar um conjunto de elementos intangíveis que são determinantes do desempenho das instituições. Nesse sentido, utilizou-se dos seguintes indicadores:
a) Motivação da equipe
b) Sabotagem de integrantes da equipe
c) Comprometimento com o trabalho 
Na Tabela 21 foi analisado o grau de Motivação da Equipe. No geral, os Gestores avaliam sua equipe como bastante motivadas, sendo que $49,1 \%$ afirmam que as equipes possuem grande motivação, $38,2 \%$ que possuem motivação mediana, $7,3 \%$ pouca motivação e 5,5\% com motivação muito grande. Nesta amostra, nenhum Gestor avaliou sua equipe como com muito pouca motivação.

Tabela 21: Grau de Motivação da Equipe

\begin{tabular}{llll}
\hline Indicador & Grau de Motivação & F & \% \\
\hline Como você avalia, no & Muito pouco & 0 & 0 \\
geral, o grau de & Pouco & 4 & 7,3 \\
motivação ao trabalho de & Médio & 21 & 38,2 \\
sua equipe? & Grande & 27 & 49,1 \\
& Muito Grande & 3 & 5,5 \\
\hline \hline Total & & 55 & 100,0 \\
\hline Fonte: Elaboração própria. & & &
\end{tabular}

Fonte: Elaboração própria.

Quanto a existência de colaboradores com hábitos de sabotagem dentro da instituição, este indicador se mostrou bastante distribuído, 27,3\% afirmaram haver muito pouca sabotagem dentro de sua instituição, 18,2\% haver pouca sabotagem, 20\% sabotagem média, 23,6 haver grande quantidade sabotagem e 9,1\% muito grande sabotagem. Neste indicador, um dos Gestores pesquisado não o respondeu (Tabela 22).

Tabela 22: Grau de Sabotagem

\begin{tabular}{llll}
\hline Indicador & Grau de Sabotagem & F & \% \\
\hline Como você avalia, no & Muito pouco & 15 & 27,8 \\
geral, o grau de & Pouco & 10 & 18,5 \\
Sabotagem ao trabalho de & Médio & 11 & 20,4 \\
sua equipe? & Grande & 13 & 24,1 \\
& Muito Grande & 5 & 9,3 \\
\hline \hline Total & & 54 & 100,0 \\
\hline
\end{tabular}

Fonte: Elaboração própria. 
Na Tabela 23, metade (50,0\%) dos Gestores afirmou haver um grau de Motivação por Função Comissionada entre grande e muito grande em sua equipe, $27,8 \%$ haver motivação mediana, 9,3\% haver pouca motivação por função comissionada e $13 \%$ haver muito pouca motivação em sua equipe. Também, nesse constructo, um dos Gestores não respondeu ao questionado.

Tabela 23: Grau de Motivação por função comissionada

\begin{tabular}{llll}
\hline Indicador & Grau de Motivação & F & \% \\
\hline Como você avalia, no & Muito pouco & 7 & 13,0 \\
geral, o grau de & Pouco & 5 & 9,3 \\
motivação por função & Médio & 15 & 27,8 \\
comissionada? & Grande & 23 & 42,6 \\
& Muito Grande & 4 & 7,4 \\
\hline \hline Total & & 54 & 100,0 \\
\hline
\end{tabular}

Fonte: Elaboração própria.

$\mathrm{Na}$ Tabela 24, 35,2\% dos Gestores afirmaram que sua equipe possui comprometimento mediano com o trabalho, $22,2 \%$ afirmaram que existe grande comprometimento e outros $22,2 \%$ que existe pouco comprometimento, $11,1 \%$ de que sua equipe tem uma motivação muito grande e $9,3 \%$ de que sua equipe possui muito pouco comprometimento. Também nesse caso, um dos pesquisados se absteve de responder.

Tabela 24: Grau de Comprometimento da Equipe

\begin{tabular}{llll}
\hline Indicador & Grau de Comprometimento & F & \% \\
\hline No geral, quando precisa & Muito pouco & 5 & 9,3 \\
sua equipe trabalha além & Pouco & 12 & 22,2 \\
do horário de serviço, ou & Médio & 19 & 35,2 \\
nas férias? & Grande & 12 & 22,2 \\
& Muito Grande & 6 & 11,1 \\
\hline \hline Total & & 55 & 100,0 \\
\hline Fonte: Elaboração própria. & & &
\end{tabular}




\subsubsection{Descrição dos indicadores de Percepção de Desempenho}

Este constructo refere-se ao conceito de desempenho orçamentário compartilhado pelos Gestores, assim, quanto mais próxima este conceito for do conceito definido neste trabalho, mais a instituição o perseguirá. Fizeram parte desse constructo:

a) Quantidade de Desperdício da instituição;

b) Conceito de Desempenho Orçamentário;

c) Conceito de Produtividade do Gasto Público;

Do total da amostra, 38,2\% informaram que possui um grau de desperdício mediano sem seu campus, 32,7\% haver ñpoucoò desperdício, 14,5\% haver ñgrandeò desperdício, $12,7 \%$ haver ñmuito poucoòe apenas $1,8 \%$ informou ser ñmuito grandeò o desperdício em seu campus (Tabela 25).

Tabela 25: Grau de Desperdício do campus

\begin{tabular}{llcc}
\hline Indicador & Desperd_PD & F & \% \\
\hline Qual o grau de & Muito pouco & 7 & 12,7 \\
desperdício que vocês & Pouco & 18 & 32,7 \\
possuem em seu campus? & Médio & 21 & 38,2 \\
& Grande & 8 & 14,5 \\
& Muito Grande & 1 & 1,8 \\
\hline \hline Total & & 55 & 100,0 \\
\hline Fonte: Elaboração própria. & & &
\end{tabular}

Na Tabela 26 nota-se que 54,5\% dos Gestores respondentes compartilham do conceito de gasto público defendido neste trabalho, outros $43,6 \%$ se opuseram a esta definição.

Tabela 26: Conceito de Desempenho

\begin{tabular}{llll}
\hline Indicador & Desemp_PD & F & $\%$ \\
\hline Você considera que o aumento da & Não & 24 & 43,6 \\
quantidade de recurso financeiro & Sim & 30 & 54,5 \\
destinado a investimento é resultado & & & \\
do uso eficiente do gasto em custeio? & & 55 & 100,0 \\
\hline \hline Total & & &
\end{tabular}


Estes percentuais praticamente não se alteram ao se analisar o resultado do indicador que questiona ao Gestor se ele acredita que o gasto em investimento é mais produtivo que o gasto em custeio, assim, obteve-se 58,2\% afirmando que ñsimò, o gasto em investimento é mais produtivo que o gasto em custeio, e $41,8 \%$ afirmando o oposto (Tabela 27).

Tabela 27: Produtividade Macroeconômica do Gasto em Investimento

\begin{tabular}{llcc}
\hline Indicador & Produt_PD & F & \% \\
\hline Em termos macroeconômicos, você acredita que o & Não & 23 & 41,8 \\
gasto em investimento é mais produtivo que o & Sim & 32 & 58,2 \\
gasto em custeio? & & & \\
\hline \hline Total & & 55 & 100,0 \\
\hline Fonte: Elaboração própria. & & &
\end{tabular}

Por fim, este constructo sondou se o Gestor acreditava ter um campus com pouco desperdício, 30,9\% acreditam haver ñpoucoò desperdício, 25,5\% um desperdício mediano, 23,6\% um ñgrandeò desperdício, apenas 10,9 o considerou ñmuito grandeò e outros $9,1 \%$ ñmuito pequenoò (Tabela 28).

Tabela 28: Percepção de desperdiço do campus

\begin{tabular}{llcc}
\hline Indicador & Recon_CG & F & \% \\
\hline Você considera o seu campus uma & Muito pouco & 5 & 9,1 \\
maquina enxuta? Sem gastos & Pouco & 17 & 30,9 \\
desnecessários? & Médio & 14 & 25,5 \\
& Grande & 13 & 23,6 \\
& Muito Grande & 6 & 10,9 \\
\hline \hline Total & & 55 & 100,0 \\
\hline
\end{tabular}

Fonte: Elaboração própria.

\subsubsection{Descrição dos indicadores de Características Organizacionais}

As Características Organizacionais diz respeito ao perfil da organização, fizeram parte desse constructo:

a) Qualidade do Staff

b) Experiência Ocupacional Pregressa da Equipe

c) Capacitação da Equipe 
d) Sinergia no Trabalho

Tabela 29: Qualificação Equipe orçamentária

\begin{tabular}{lc}
\hline & $\begin{array}{l}\text { Como você avalia os } \\
\text { servidores envolvidos } \\
\text { com o orçamento }\end{array}$ \\
\hline Muito Pouco qualificada & $1(1,8 \%)$ \\
Pouco Qualificada & $1(1,8 \%)$ \\
Qualificação média & $8(14,5 \%)$ \\
Grande Qualificação & $26(47,3 \%)$ \\
Muito Grande Qualificada & $19(34,5 \%)$ \\
\hline \hline Total & $55(100 \%)$ \\
\hline Fonte: Elaboração própria. &
\end{tabular}

Como se observa na Tabela 29, a maioria dos Gestores considera suas equipes de Compras, Financeiro e Orçamentários entre com ñGrande Qualificaçãoò e ñMuito Grande Qualificaçãoò (81,8\%).

Já na Tabela 30, ao se questionar sobre as experiências profissionais no setor privado dos servidores envolvidos na gestão dos recursos orçamentários, 32,7\% informou ser pouca essa experiência, $27,3 \%$ ser média, $20 \%$ ser grande e $16,4 \%$ ser muito pouca.

Tabela 30: Experiência Profissional Pregressa dos Servidores ligados ao Orçamento

\begin{tabular}{llcc}
\hline Indicador & ExperProf_CO & F & $\mathbf{\%}$ \\
\hline No Geral, o quadro de servidores & Muito pouco & 9 & 16,4 \\
envolvidos na Gestão dos Recursos & Pouco & 18 & 32,7 \\
Financeiros possui experiência & Médio & 15 & 27,3 \\
profissional na área privada? & Grande & 11 & 20,0 \\
& Muito Grande & 2 & 3,6 \\
\hline \hline Total & & 55 & 100,0 \\
\hline
\end{tabular}

Fonte: Elaboração própria.

Outro indicador em que se tentou sondar no constructo ñCaracterísticas Organizacionaisò foi sobre a quantidade, em horas, de capacitação que a equipe que lida com o orçamento realiza anualmente, assim, obteve-se que 32,7\% dos Gestores responderam que sua equipe realiza de 25 a 48 horas de capacitação por ano, 29,1\% de 12 a 24 horas, 27,3\% acima de 48 horas (Tabela 31). 
Tabela 31: Tempo de Capacitação da Equipe ligada ao Orçamento

\begin{tabular}{llcc}
\hline Indicador & CapacEqui_CO & F & \% \\
\hline Quantas horas de treinamento, em & Menos de 12 horas & 6 & 10,9 \\
média, os servidores envolvidos com & De 12 a 24 horas & 16 & 29,1 \\
o orçamento realizam por ano, & De 25 a 48 horas & 18 & 32,7 \\
individualmente? & Acima de 48 horas & 15 & 27,3 \\
\hline \hline Total & & 55 & 100,0 \\
\hline
\end{tabular}

Fonte: Elaboração própria.

Por fim, questionou-se sobre o grau de sinergia existente no campus, mais da metade $(52,7 \%)$ informaram que possuem ñGrandeò sinergia dentro do seu campus, $29,1 \%$ que sua sinergia é ñmuito grandeò, 3,6\% informou que havia ñpoucaò sinergia. Ressalta-se que nenhum Gestor assinalou haver ñmuito poucaò sinergia dentro de seu campus (Tabela 32).

Tabela 32: Sinergia entre os Colaboradores

\begin{tabular}{llcc}
\hline Indicador & Sinerg_CG & F & \% \\
\hline Qual o grau de sinergia & Muito pouco & 0 & 0 \\
compartilhado entre seus & Pouco & 2 & 3,6 \\
colaboradores? & Médio & 8 & 14,5 \\
& Grande & 29 & 52,7 \\
& Muito Grande & 16 & 29,1 \\
\hline \hline Total & & 55 & 100,0 \\
\hline
\end{tabular}

Fonte: Elaboração própria. 


\subsection{Teste de Hipóteses İ Inferências Parciais por Indicador}

\subsubsection{Teste de Hipótese $\mathbf{H}_{0,1}$ - Indicadores de Capital Humano}

Foram testados, nesse constructo, quatro indicadores (Escol_CH, ExpeerProf_CH, ExperLider_CH e ExperCarg_CH), todos utilizando o desempenho orçamentário como variável dependente. Assim, procederam-se quatro Regressões Lineares Simples. O resultado está demonstrado no Quadro 07.

\section{Quadro 7: Teste dos indicadores de ñCapital Humanoò}

\begin{tabular}{|lll|}
\hline Indicador & $\mathbf{R}^{\mathbf{2}}$ & $\boldsymbol{p}$ \\
Escol_CH & 0,000 & 0,886 \\
ExpeerProf_CH & 0,006 & 0,578 \\
ExperLider_CH & 0,000 & 0,985 \\
ExperCarg_CH & 0,019 & 0,321 \\
\hline Fonte:Elaboração & Própria.
\end{tabular}

Conforme se observa, nenhum dos indicadores do constructo ñCapital Humanoò, individualmente, se mostrou relevante para explicar o comportamento da taxa de investimento dos campi. O que permite afirmar que os indicadores de ñCapital Humanoò, nesta amostra, não são determinantes da qualidade do gasto público dos Institutos Federais. Assim, as hipóteses nulas foram aceitas para os indicadores, conforme Tabela 33:

Tabela 33: Sumário das hipóteses ï Indicadores de Capital Humano

\begin{tabular}{ccc}
\hline Indicador & $\mathbf{H}_{\mathbf{0}}$ & $\mathbf{H}_{\mathbf{1}}$ \\
\hline Escol_CH & $\mathrm{X}$ & \\
ExpeerProf_Ch & $\mathrm{X}$ & \\
ExperLider_CH & $\mathrm{X}$ & \\
ExperCarg_CH & $\mathrm{X}$ & \\
\hline Fonte:Elaboração Própria. & &
\end{tabular}




\subsubsection{Teste de Hipótese $\mathbf{H}_{0,2-}$ Indicadores de Capital Social}

Procedeu-se a mesma análise, Regressão Linear Simples, junto aos quatro indicadores do constructo ñCapital Socialò(CoopExt_CS, Consult_CS, InstPubParc_CS e CoopExt2_CS), de maneira individual, obtendo os valores do Quadro 8:

\section{Quadro 8: Teste dos indicadores de ñCapital Socialò.}

\begin{tabular}{|lll} 
Indicador & $\mathbf{R}^{2}$ & $\boldsymbol{p}$ \\
CoopExt_CS & 0,007 & 0,550 \\
Consult_CS & 0,015 & 0,383 \\
InstPubParc3_CS & 0,000 & 0,995 \\
CoopExt2_CS & 0,000 & 0,944 \\
\hline Fonte: Elaboração Própria.
\end{tabular}

Conforme pode ser observado, nenhum dos indicadores, individualmente, se mostrou relevante para determinar o comportamento orçamentário dos Institutos Federais. Ao que permite concluir que, nesta amostra, os dados afirmam que os indicadores de ñCapital Socialò não são determinantes da qualidade do gasto público dos Institutos Federais (Tabela 34). Aceitando as hipóteses nulas também para este constructo.

Tabela 34: Sumário das hipóteses ï Indicadores de Capital Social

\begin{tabular}{ccc}
\hline Indicador & $\mathbf{H}_{\mathbf{0}}$ & $\mathbf{H}_{\mathbf{1}}$ \\
\hline CoopExt_CS & $\mathrm{X}$ & \\
Consult_CS & $\mathrm{X}$ & \\
InstPubParc_CS & $\mathrm{X}$ & \\
CoopExt2_CS & $\mathrm{X}$ & \\
\hline
\end{tabular}

Fonte:Elaboração Própria.

\subsubsection{Teste de Hipótese $\mathbf{H}_{0,3-}$ - Indicadores de Características Gerenciais}

Quatro indicadores constituíram a constructo ñCaracterísticas Gerenciaisò, sendo eles: IngPol_CG, Planej_CS, Buroc_CG e Recon_CG. Analisando cada indicador, pela Regressão Linear Simples, obteve-se os dados explicitados no Quadro 9. 


\section{Quadro 9: Teste dos indicadores de ñCaracterísticas Gerenciaisò}

\begin{tabular}{|lll|}
\hline Indicador & $\mathbf{R}^{\mathbf{2}}$ & $\boldsymbol{p}$ \\
\hline IngPol_CG & 0,051 & 0,100 \\
Planej_CG & 0,057 & 0,079 \\
Buroc_CG & 0,041 & 0,142 \\
Recon_CG & 0,036 & 0,168 \\
\hline Fonte:Elaboração Própria.
\end{tabular}

Pelo fato de os sinais obtidos nas variáveis Planej_CG (Planejamento), Recon_CG (Reconhecimento Profissional dos colaboradores) e Buroc_CG (Enrijecimento Burocrático do Campus) terem sido diferentes do teorizado, houve a necessidade de eliminá-las da análise. Restando apenas, para análise do constructo, uma única variável, a qual se mostrou relevante estatisticamente (IngPol_CG).

Ao se aprofundar na análise desse indicador, nota-se que o poder de explicação desta variável em relação a variável dependente é bastante pequeno, em torno de $5,1 \%$ e pôde ser validado pelo teste ANOVA $(F=2,80$ e $P<0,05$, por se tratar de uma variável com características unicaudal).

Tabela 35: Coeficientes de Regressão ï Características Gerenciais

\begin{tabular}{|c|c|c|c|c|c|}
\hline Modelo & $\begin{array}{c}\text { Coef } \\
\text { pac }\end{array}$ & $\begin{array}{l}\text { ientes não } \\
\text { onizados } \\
\text { Erro padrão }\end{array}$ & $\begin{array}{l}\text { Coeficientes } \\
\text { padronizados } \\
\text { Beta }\end{array}$ & $\mathbf{t}$ & Sig. \\
\hline Constante & 37,972 & 3,930 & & 9,663 & 0,000 \\
\hline IngPol_CG & $-2,444$ & 1,459 & $-0,226$ & $-1,676$ & 0,100 \\
\hline
\end{tabular}

Fonte: Elaboração Própria

Dessa forma, o modelo estimado resultante da análise é dado por:

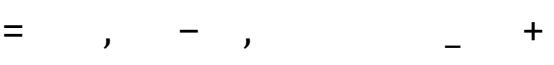

Por fim, após análise dos valores expelidos pelo SPSS, pode-se concluir que, nesta amostra, apenas o indicador referente a Ingerências Políticas (jogos políticos dentro da 
instituição) é determinante da qualidade do gasto público dos Institutos Federais (Tabela 36). Rejeitando a hipótese nula para este indicador e aceitando para os demais.

Tabela 36: Sumário das hipóteses ï Indicadores de Características Gerenciais

\begin{tabular}{lcc}
\hline Indicador & $\mathbf{H}_{\mathbf{0}}$ & $\mathbf{H}_{\mathbf{1}}$ \\
\hline IngPol_CG & & $\mathrm{X}$ \\
Planej_CS & $\mathrm{X}$ & \\
Buroc_CG & $\mathrm{X}$ & \\
Recon_CG & $\mathrm{X}$ & \\
\hline
\end{tabular}

Fonte:Elaboração Própria.

\subsubsection{Teste de Hipótese $\mathbf{H}_{0,4}$ - Indicadores de Motivação e Cultura}

Neste constructo incluíram-se quatro indicadores (MotivEquip_MC, Sabot_MC, MotFunç_MC e Comprom_MC), numa tentativa de se explicar o desempenho por meio de elementos intangíveis da instituição. Assim, obteve-se como resultado, após analisar cada indicador, por meio da Regressão Linear Simples, que nenhum dos indicadores se mostrou significativo estatisticamente (Quadro 10).

\section{Quadro 10: Teste dos indicadores de ñMotivação e Culturaò}

\begin{tabular}{|cll|}
\hline Indicador & $\mathbf{R}^{\mathbf{2}}$ & $\boldsymbol{p}$ \\
MotivEquip_MC & 0,028 & 0,224 \\
Sabot_MC & 0,009 & 0,506 \\
MotFunç_MC & 0,014 & 0,389 \\
Comprom_MC & 0,010 & 0,462 \\
\hline
\end{tabular}

Fato que permite afirmar que os indicadores de ñMotivação e Culturaò não são determinantes da qualidade do gasto público dos Institutos Federais. Aceitando a hipótese nula para todo o constructo (Tabela 37). 
Tabela 37: Sumário das hipóteses ï Indicadores de Motivação e Cultura

\begin{tabular}{lcc}
\hline Indicador & $\mathbf{H}_{\mathbf{0}}$ & $\mathbf{H}_{\mathbf{1}}$ \\
\hline MotivEquip_MC & $\mathrm{X}$ & \\
Sabot_MC & $\mathrm{X}$ & \\
MotFunç_MC & $\mathrm{X}$ & \\
Comprom_MC & $\mathrm{X}$ & \\
\hline Fonte:Elaboração Própria. &
\end{tabular}

\subsubsection{Teste de Hipótese $\mathbf{H}_{0,5-}$ - Indicadores de Percepção de Desempenho}

Neste constructo, foram utilizadas quatro indicadores (Desper_PD, Desemp_PD, Prod_PD e Desper2_PD) no intuito de identificar se o conceito de desempenho idealizado pelo gestor coaduna com o proposto neste trabalho, assim, em tese, quanto maior o consenso deste desempenho, mais a instituição o busca.

\section{Quadro 11: Teste dos indicadores de ñPercepção de Desempenhoò}

\begin{tabular}{|cll|} 
Indicador & $\mathbf{R}^{\mathbf{2}}$ & $\boldsymbol{p}$ \\
Desper_PD & 0,049 & 0,105 \\
Desemp_PD & 0,165 & 0,002 \\
Prod_PD & 0,291 & 0,000 \\
Desper2_PD & 0,234 & 0,000 \\
\hline
\end{tabular}

Fonte: Elaboração Própria.

Como se observa do Quadro 11, três dos quatro indicadores se mostraram significativos individualmente $(p<0,05)$, são eles: Conceito de Desempenho Orçamentário (Desemp_PD), Conceito de Produtividade do Gasto Público (Prod_PD) e Noção de Desperdício concebida pelo Gestor (Desper2_PD).

Ao se debruçar sobre o poder de explicação de cada variável, nota-se que o indicador Desemp_PD possui poder de explicação de $16,5 \%$ da variabilidade da variável dependente; o indicador Prod_PD, de 29,1\% e o indicador Desper2_PD, de 23,4\%, respectivamente.

Já ao se analisar o modelo resultante, obtém-se: 
Tabela 38: Coeficientes de Regressão ï variável Desemp_PD

\begin{tabular}{|c|c|c|c|c|c|}
\hline \multirow[t]{2}{*}{ Modelo } & \multicolumn{2}{|c|}{$\begin{array}{l}\text { Coeficientes não } \\
\text { padronizados }\end{array}$} & \multirow{2}{*}{$\begin{array}{l}\text { Coeficientes } \\
\text { padronizados } \\
\text { Beta }\end{array}$} & \multirow[t]{2}{*}{$\mathbf{t}$} & \multirow[t]{2}{*}{ Sig. } \\
\hline & 6 & Erro padrão & & & \\
\hline Constante & 37,23 & 2,35 & & 15,83 & 0,000 \\
\hline Desemp_PD & 11,31 & 3,52 & 0,406 & 3,20 & 0,002 \\
\hline
\end{tabular}

Em que o modelo estimado pela variável Desemp_PD é dado por:

Da análise da variável Prod_PD, chega-se:

Tabela 39: Coeficientes de Regressão ï variável Prod_PD

\begin{tabular}{|c|c|c|c|c|c|}
\hline \multirow[t]{2}{*}{ Modelo } & \multicolumn{2}{|c|}{$\begin{array}{c}\text { Coeficientes não } \\
\text { padronizados }\end{array}$} & \multirow{2}{*}{$\begin{array}{l}\text { Coeficientes } \\
\text { padronizados } \\
\text { Beta }\end{array}$} & \multirow[t]{2}{*}{$\mathbf{t}$} & \multirow[t]{2}{*}{ Sig. } \\
\hline & 6 & Erro padrão & & & \\
\hline Constante & 38,47 & 2,07 & & 18,517 & 0,000 \\
\hline Prod_PD & 14,99 & 3,21 & 0,540 & 4,667 & 0,000 \\
\hline
\end{tabular}

Fonte: Elaboração Própria

O modelo resultante é dado por:

Por fim, chega-se ao modelo resultante da última variável significante:

Tabela 40: Coeficientes de Regressão ï variável Desper2_PD

\begin{tabular}{|c|c|c|c|c|c|}
\hline Modelo & $\begin{array}{r}\text { Coefi } \\
\text { pad }\end{array}$ & entes não & $\begin{array}{l}\text { Coeficientes } \\
\text { padronizados }\end{array}$ & $\mathbf{t}$ & Sig. \\
\hline Constante & 15,247 & 4,522 & & 3,372 & 0,001 \\
\hline Deseper2_PD & 5,722 & 1,421 & 0,484 & 4,027 & 0,000 \\
\hline
\end{tabular}

Fonte: Elaboração Própria

E o modelo resultante é dado por: 
Assim, após análise dos valores extraídos pelo SPSS, pode-se concluir que, nesta amostra, os indicadores Desemp_PD, Prod_PD e Desper2_PD são determinantes da qualidade do gasto público dos Institutos Federais (Tabela 41). Rejeitando as hipóteses nulas para estes indicadores e aceitando para o indicador Desper_PD.

Tabela 41: Sumário das hipóteses ï Indicadores de Percepção de Desempenho

\begin{tabular}{lcc}
\hline Indicador & $\mathbf{H}_{\mathbf{0}}$ & $\mathbf{H}_{\mathbf{1}}$ \\
\hline Desper_PD & $\mathrm{X}$ & \\
Desemp_PD & & $\mathrm{X}$ \\
Prod_PD & $\mathrm{X}$ \\
Desper2_PD & $\mathrm{X}$ \\
\hline Fonte:Elaboração Própria. &
\end{tabular}

\subsubsection{Teste de Hipótese $H_{0,6-}$ - Indicadores de Características Organizacionais}

Para este constructo, buscou-se explicar o desempenho orçamentário dos Institutos Federais por meio de características intrínsecas a organização, para tanto, utilizou-se dos seguintes indicadores: ServOrcam_CO, ExpProf_CO, CapacEqu_CO e Sinerg_CO.

\section{Quadro 12: Teste dos indicadores de Características Organizacionais}

\begin{tabular}{|lll|}
\hline Indicador & $\mathbf{R}^{\mathbf{2}}$ & $\boldsymbol{p}$ \\
ServOrcam_CO & 0,003 & 0,714 \\
ExpProf_Co & 0,071 & 0,049 \\
CapacEqu_CO & 0,331 & 0,014 \\
Sinerg_CO & 0,050 & 0,102 \\
\hline Fonte:Elaboração Própria.
\end{tabular}

Conforme se observa no Quadro 12, dois dos indicadores se mostraram significativos, sendo eles: ExpProf_CO (Experiência profissional pregressa da equipe que trabalha com o orçamento) e CapacEqu_CO (Horas de Capacitação da equipe que trabalha com o orçamento). Entretanto, o primeiro indicador obteve sinal diverso do preconizado, fato que o excluiu da análise. Já quanto a variável CapacEqu_CO, esta obteve uma capacidade preditiva da variável dependente de $33 \%$. E o sinal resultante foi igual ao sinal preconizado no modelo teórico (Tabela 42): 
Tabela 42: Coeficientes de Regressão ï variável CapacEqu_CO

\begin{tabular}{|c|c|c|c|c|c|}
\hline \multirow[t]{2}{*}{ Modelo } & \multicolumn{2}{|c|}{$\begin{array}{l}\text { Coeficientes não } \\
\text { padronizados }\end{array}$} & \multirow{2}{*}{$\begin{array}{l}\text { Coeficientes } \\
\text { padronizados } \\
\text { Beta }\end{array}$} & \multirow[t]{2}{*}{$\mathbf{t}$} & \multirow[t]{2}{*}{ Sig. } \\
\hline & 6 & Erro padrão & & & \\
\hline Constante & 23,97 & 3,68 & & 6,51 & 0,000 \\
\hline CapacEqu_CO & 4,66 & 1,82 & 0,331 & 2,55 & 0,014 \\
\hline
\end{tabular}

Assim, estimou-se este modelo em:

$=\quad+\quad+\quad+$

Dessa forma, pode-se concluir que, nesta amostra, apenas o indicador referente a Capacitação da Equipe que trabalha com Orçamento é determinantes da qualidade do gasto público dos Institutos Federais (Tabela 43). Rejeitando as hipóteses nulas para esta variável e aceitando para as demais.

Tabela 43: Sumário das hipóteses ï Indicadores de Características Organizacionais

\begin{tabular}{lcc}
\hline Indicador & $\mathbf{H}_{\mathbf{0}}$ & $\mathbf{H}_{\mathbf{1}}$ \\
\hline ServOrcam_CO & $\mathrm{X}$ & \\
ExpProf_Co & $\mathrm{X}$ & \\
CapacEqu_CO & & $\mathrm{X}$ \\
Sinerg_CO & $\mathrm{X}$ & \\
\hline
\end{tabular}

Fonte:Elaboração Própria. 


\subsection{Modelo Geral Proposto}

Após testar o modelo geral proposto, utilizando-se do método Step Wise, com todas as variáveis explicativas válidas, a Análise da Regressão Linear Múltipla encontrou:

\section{Quadro 13: Regressão linear com o Modelo Geral Proposto.}

\begin{tabular}{|ccc|}
\hline Constructo & $\mathbf{R}^{\mathbf{2}}$ & $\boldsymbol{p}$ \\
Modelo Geral Proposto & 0,508 & 0,000 \\
\hline
\end{tabular}

Fonte:Elaboração Própria.

Como se observa, a função final foi capaz de explicar 50,8\% da variabilidade da variável dependente, relativamente alto a considerar que se trata de uma pesquisa do tipo exploratória, além da pouca quantidade de variável que se mostrou significativa. Nota-se também que o modelo possuiu uma significância estatística de 100\% ( $p=0,00)$ (Quadro 13).

Tabela 44: Coeficientes de Regressão ï Modelo Geral

\begin{tabular}{|c|c|c|c|c|c|}
\hline Modelo & $\begin{array}{l}\text { Coefi } \\
\text { pad }\end{array}$ & $\begin{array}{l}\text { ientes não } \\
\text { onizados }\end{array}$ & $\begin{array}{l}\text { Coeficientes } \\
\text { padronizados }\end{array}$ & $\mathbf{t}$ & Sig. \\
\hline Constante & 15,708 & 4.824 & & 3.256 & 0.002 \\
\hline IngPol_CG & $-2,112$ & 1,074 & $-0,196$ & $-1,967$ & 0,055 \\
\hline Prod_PD & 13,450 & 2,852 & 0,481 & 4,716 & 0,000 \\
\hline Desper2_PD & 4,586 & 1,241 & 0,377 & 3,695 & 0,001 \\
\hline
\end{tabular}

Fonte: Elaboração Própria

O modelo geral ficou estimado em:

$$
\text { = 15,70 ï 2,11 IngPol_CG + 13,4 Prod_PD + 4,5 Desper2_PD + U゚ }
$$

Dessa forma, pode-se concluir que, ao se analisar o modelo geral, nesta amostra, somente três indicadores se mostraram determinantes da qualidade do gasto público nos 
Institutos Federais (Tabela 45). Rejeitando as hipóteses nulas para estes e aceitando para os demais.

Tabela 45: Indicadores no Modelo Geral

\begin{tabular}{lll}
\hline Constructo & $\mathbf{H}_{\mathbf{0}}$ & $\mathbf{H}_{\mathbf{1}}$ \\
\hline Escol_CH & $\mathrm{X}$ & \\
ExperProf_CH & $\mathrm{X}$ & \\
ExperLider_CH & $\mathrm{X}$ & \\
ExperCarg_CH & $\mathrm{X}$ & \\
CoopExt_CS & $\mathrm{X}$ & \\
Consult_CS & $\mathrm{X}$ & \\
InstPúbParc_CS & $\mathrm{X}$ & \\
CoopExt2_CS & $\mathrm{X}$ & \\
IngerPol_CG & & $\mathrm{X}$ \\
Planej_CG & $\mathrm{X}$ & \\
Buroc_CG & $\mathrm{X}$ & \\
Recon_CG & $\mathrm{X}$ & \\
MotivEquip_MC & $\mathrm{X}$ & \\
Sabot_MC & $\mathrm{X}$ & \\
MotFunç_MC & $\mathrm{X}$ & \\
Comprom_MC & $\mathrm{X}$ & \\
Desperd_PD & $\mathrm{X}$ & \\
Desempe_PD & $\mathrm{X}$ & \\
Prod_PD & & $\mathrm{X}$ \\
Desperd2_PD & & $\mathrm{X}$ \\
ServOrça_CO & $\mathrm{X}$ & \\
ExperProf_CO & $\mathrm{X}$ & \\
Capacequip_CO & $\mathrm{X}$ & \\
Sinerg_CO & $\mathrm{X}$ & \\
\hline
\end{tabular}

Fonte:Elaboração Própria. 


\subsection{Apontamentos Gerais}

Embora os Institutos Federais analisados, certamente, possuam realidades sociais e organizacionais bastantes distintas uns dos outros, neste estudo, algumas variáveis explicativas se mostraram relevantes estatisticamente na determinação do comportamento da variável dependente em toda amostra.

Claro que, com base exclusivamente nestes resultados, e por se tratar de uma pesquisa exploratória, generalizar os achados poderia forçar o pesquisador a incorrer em um erro grave, visto que, tanto a afirmação de que uma única ação ou característica específica de uma organização seja responsável por um melhor ou pior desempenho orçamentário, quanto pela afirmação oposta, de que variáveis que aqui não se mostraram relevantes não sejam determinantes da qualidade do gasto público, carece de fundamentação teórica, mas, aparentemente, se mostra ilógico.

Entretanto, merece destaque alguns dos resultados. Primeiramente, pela análise do modelo geral proposto, em que três variáveis se mostraram relevantes, quais sejam:

I. Prod_PD (Conceito macroeconômico de gasto produtivo concebido pelo Gestor): quanto mais o Gestor acredita que o gasto em investimento é mais produtivo que o gasto em custeio, mais seu campus se comportou como tal.

Esta variável demonstra, entre outras coisas, o quanto a matriz ideológica do Gestor influi diretamente no comportamento de seu campus, assim, Gestores com concepções enviesadas de seu papel podem conduzir sua organização por caminhos que, por vezes, não condizem com o interesse público. Além de colocar em realce a figura do próprio Gestor, ao evidenciar que é ele o responsável por conduzir seu campus de forma correta ou não.

II. Desper2_PD (Grau de Desperdício do campus, na visão do Gestor): a percepção dos Gestores de que seu campus possui menos gastos desnecessários, ou seja, possuem menos 
desperdício, é real, e coaduna com a quantidade de recurso destinado a rubrica investimento. Assim, campus com menos desperdício, são os que mais destinam recurso a investimento.

Por um lado, esta variável vem confirmar todo o arcabouço teórico que trata de como o setor público possui uma má qualidade em seu gasto, relembrando autores já citados como Bandiera; Prat e Valletti (2009); Ribeiro e Junior (2006); Afonso, Schuknecht e Tanzi (2005 e 2006), Motta (2010). E deixando explicito a vasta margem para melhoria desse gasto, caso fosse mais bem direcionado.

Por outro lado, ela também evidencia o que Riani (2002) havia afirmado, pelo qual quanto maior o volume de recursos gastos em compromissos correntes, mesmo sendo ele desnecessário, menor será sua capacidade de realizar investimentos.

III. IngPol_CG (Grau de Ingerências Políticas no Campus): o grau de Ingerências administrativas, decorrentes de jogos políticos, é determinante do comportamento orçamentário. Assim, quanto mais ingerência, menos resultado.

Esta variável vem confirmar o que Woodrow Wilson (1887) e o que Frank Goodnow (1900) defendiam: que a Administração Pública deveria superar as práticas patrimonialista e de ingerências políticas para poder aumentar seu desempenho. Assim, neste trabalho, os campi julgados, pelo seu Gestor, como que possuem menos ingerência política, ou seja, são mais técnicos, obtiveram melhores resultados.

O que condiz com o que Medeiros (2011, p.208) afirmou em sua tese:

A atividade de gestão, em qualquer ambiente, mas especialmente no meio escolar, é
uma atividade humana, prático-crítica, sensível e subjetiva, mas que requer, acima
de tudo, uma natureza técnica (MEDEIROS, 2011. P.208).

Já quando se analisa as variáveis explicativas individualmente, as evidências afirmam que, não só as variáveis anteriores determinam a variável dependente, como também: 
IV. Desemp_PD (Conceito de Desempenho Orçamentário): quanto mais o Gestor acredita que a destinação de recurso a rubrica investimento é sinônimo de utilização eficiente dos recursos públicos, mais seu campus se comporta como tal.

Da mesma forma que a variável Prod_PD, ganha destaque a figura do Gestor e a forma como ele pensa sobre o que seria gasto público eficiente.

V. CapacEqu_CO (Horas de Capacitação da equipe que trabalha com o orçamento): Equipes que trabalham com orçamento que possuem maior quantidade de horas de capacitação são as que possuem maior quantidade de recurso destinado a investimento.

Assim, esta variável vem evidenciar, no setor público, a lógica que Kaplan e Norton (1992) afirmam existir no setor privado, em que a capacitação dos empregados é seguida por uma melhora na eficiência dos processos, e, consequentemente, no desempenho final da organização.

Em resumo, são variáveis determinantes da qualidade do gasto público nos IF's: o conceito macroeconômico de gasto produtivo concebido pelo Gestor (Prod_PD), o conceito de desempenho orçamentário, também na visão do Gestor (Desemp_PD), o grau de desperdício do campus, na visão do Gestor (Desper2_PD), a quantidade de horas de capacitação da equipe que trabalha com o orçamento (CapacEqu_CO) e o grau de ingerências políticas no Campus (IngPol_CG).

De outra forma, cabe aqui também tentar explicar os motivos pelos quais diversas variáveis utilizadas neste trabalho não se mostraram determinantes do desempenho orçamentário nestas instituições:

O primeiro é o fato de ter-se utilizado uma grande quantidade de variáveis, de naturezas as mais diversas possíveis, no intuito de que, ao encontrar significância estatística em algumas delas, pudessem sinalizar um caminho a ser melhor explorado futuramente. Assim, foram inseridas variáveis que, a primeira vista, não possuíam grande ligação com o desempenho 
orçamentário nos Institutos Federais, mas que, caso se mostrassem significativas, poderiam sinalizar um grande achado para a Administração Pública.

Somando-se a isso, ressalta-se que o trabalho se utilizou de variáveis que se mostraram relevantes na determinação do desempenho em modelos privados. Obviamente, ao serem transmutadas para um modelo público, sua fundamentação teórica-epstemiologica perdeu consistência. Por último, trata-se de um modelo em que a variável dependente teve sua fundamentação teórica estruturada em conceitos macroeconômicos, entretanto, o mesmo não ocorreu na pesquisa, a qual se deu em um contexto micro. Podendo ter gerado vieses nos resultados.

Entretanto, com base nos resultados aqui expostos, sugerem-se novas pesquisas para aprofundamento do tema, pois tanto dos resultados que se mostraram significativos, quanto os que não se mostram, podem ser melhor explorados, a fim de encontrar outras possíveis explicações para tal comportamento.

Por fim, é bom lembrar que não se pode, inocentemente, acreditar que é apenas a busca pela obtenção destas ações, ditas nesse trabalho como determinante da qualidade do gasto público, que garantirá ao Instituto Federal um bom desempenho orçamentário, mas sim a capacidade, sensibilidade e, principalmente, a vontade dos Gestores e servidores envolvidos com recursos públicos em perceber os diversos fatores, nuances e oportunidades que o cercam e tentar guiá-los na consecução do maior objetivo da Instituição: o interesse público. 


\section{CONSIDERAÇÕES FINAIS}

O presente trabalho de pesquisa tratou de analisar os principais indicadores determinantes da qualidade do gasto público presentes nas unidades da Rede Federal de Ensino Profissional, Científica e Tecnológica, no que tange a eficiência alocativa dos recursos, sob uma perspectiva de que os gastos em investimentos são preferíveis àqueles em custeio.

Para tanto, foi proposto um modelo geral, em que se buscaram identificar e testar possíveis dimensões teóricas que fossem capazes de explicar o desempenho orçamentário nessas unidades da Rede Federal de Ensino Profissional. Nesse sentido, os indicadores explicativos do desempenho foram divididos em seis constructos: 1) Capital Humano; 2) Capital Social; 3) Características Gerenciais; 4) Motivação e Cultura; 5) Percepção de Desempenho e 6) Características Organizacionais.

Cada um desses indicadores converteu-se em hipóteses de pesquisas, os quais foram testados individualmente e como um todo, por meio da Análise de Regressão. Do modelo geral utilizado para testar os fatores influentes, verificou-se que apenas os indicadores Prod_PD (Conceito macroeconômico de gasto produtivo concebido pelo Gestor), Desper2_PD (Grau de Desperdício do campus, na visão do Gestor) e IngPol_CG (Grau de Ingerências Políticas no Campus) se mostraram relevantes.

Dessa forma, a partir das evidencias encontradas nessa amostra, rejeita-se a hipótese nula para os indicadores: Prod_PD, Desper2_PD e IngPol_CG. Não rejeitando as hipóteses nulas para os demais, por não se ter encontrado evidencias significativas para isso. Ao se analisar os indicadores individualmente, além destes acima citados, também se fizeram relevantes os indicadores Desemp_PD (Conceito de Desempenho Orçamentário concebido 
pelo Gestor) e CapacEqu_CO (Horas de Capacitação da equipe que trabalha com o orçamento).

Diante desses resultados, alguns apontamentos podem emergir de forma a servir de subsídio para formulação de estratégias e/ou políticas públicas voltadas ao fomento desse comportamento orçamentário, tido nesse trabalho como diretamente relacionado à qualidade do gasto público. O primeiro refere-se à criação de algum meio de conscientização dos gestores públicos da relevância que o gasto em investimento possui no contexto econômico, pois esta foi a variável explicativa de maior relevância estatística e maior poder explicativo da variável dependente. Sendo crucial para que o Estado consiga aumentar seus gastos em investimento.

O segundo diz respeito à necessidade de se reduzir os desperdícios existentes dentro das unidades educacionais, pois este foi outro indicador que se mostrou relevante e necessário para que haja maior destinação de recurso a investimento. Assim, sugere-se que o Governo ou mesmo o CONIF (Conselho Nacional das Instituições da Rede Federal de Educação Profissional, Científica e Tecnológica) criem meios de divulgação de boas práticas ou outras medidas possíveis que intentem proporcionar economia de recurso público na manutenção das instituições.

Ademais, sugerir aos Gestores que capacitem suas equipes de trabalho, principalmente as que trabalham diretamente com recursos público, ou que evitem ingerências políticas sobre as técnicas dentro da instituição, parecem recomendações um tanto obvias para melhoria do desempenho orçamentário ou qualquer outro tipo de desempenho organizacional almejado.

Também, ressalta-se que alguns desses apontamentos possuem relevância para a Academia, para a Sociedade e, principalmente, para os Gestores de instituições de educação em geral. Para a Academia porque amplia e instiga novas pesquisas e discussões relacionadas ao tema, tanto do ponto de vista das ciências econômicas como das ciências administrativas. 
Para a Sociedade, pois são eles os principais beneficiados de uma instituição de ensino bem administrada, não só pelos benefícios diretos ligados ao produto do ensino, pesquisa e extensão, mas também pelo impulso ao crescimento econômico que os gastos dessa instituição podem proporcionar numa economia regional.

E, para os Gestores de Instituições de ensino, pois fornece uma nova perspectiva norteadora de suas responsabilidades, evidenciando fatores cruciais que influenciam em seus resultados, bem como pela ampliação da visão do próprio papel que as instituições educacionais possuem dentro de uma região.

Ressalta-se que esta investigação teve caráter pioneiro e, por este motivo, possuiu diversas limitações, as quais se tentaram superar neste trabalho. Certamente, algumas dessas dificuldades observadas no decorrer dos trabalhos influenciaram diretamente nos resultados obtidos, além de que sua evidenciação servirem para orientar futuros pesquisadores nessa seara. A primeira delas diz respeito à escolha dos casos para estudo, visto que uma grande parte dos Institutos não possuía dados disponíveis no Portal da Transparência, obrigando-se a restringir a amostra à quase metade dos casos selecionados inicialmente. Outro ponto que poderia ter enviesado as análises, corresponde aos gestores respondentes do questionário, pois é sabido que nem todo gestor possui tamanha quantidade de informação a respeito de sua instituição, podendo, por vezes, terem respondido alguns indicadores com informações não verídicas.

Acresce-se também que pelo próprio fato de ter se utilizado de indicadores que se mostraram relevantes no setor privado, a fundamentação teórica para formulação do questionário careceu de profundidade teórica-epistemológico. Por isso, é necessário destacar, a priori, até mesmo pela complexidade do tema, que não se teve a pretensão de exauri-lo por completo, mas de percorrer os pontos principais das abordagens, visto que o debate tem méritos em si. 
De outra forma, espera-se que este trabalho possa instigar os Gestores de instituições educacionais a se esforçarem para destinação de mais recursos a rubrica investimento, visto que, assim, sua instituição contribuirá não só com sua finalidade precípua, mas também com o desenvolvimento regional. E, é somente com a conscientização desse caráter técnico, presente na Gestão, que o poder público poderá atender de forma satisfatória ao interesse público, motivo único que fundamenta sua própria existência. 


\section{REFERÊNCIAS}

AFONSO, A.; SCHUKNECHT, L. e TANZI, V. Public Sector Efficiency: An International Comparison. Public Choice, 123 (3-4), 321-347. 2005.

AFONSO, A.; SCHUKNECHT, L. e TANZI, V. Public Sector Efficiency: Evidence for New EU Member States and Emerging Markets. BCE Working Paper 581. 2006.

ALBANO SANTOS; J. Economia Pública. $2^{\circ}$ Edição. Coleção: Manuais Pedagógicos. Editora: Instituto Superior de Ciências Sociais e Políticas. 2012.

ALEXANDRINO, Marcelo; PAULO, Vicente. Direito Administrativo. 12. ed. Rio de Janeiro; Impetus 2010.

ASCHAUER, D. Is Public Expenditure Productive? Journal of Monetary Economics, v.23, p.177-200, Mar.1989.

BANDIERA, O.; PRAT, A.; VALLETTI, T. Active and Passive Waste in Government Spending: evidence from a policy experiment. The Economics of Public Procurement. American Economic Review, p.1278-1308, 2009.

BARTHOLO, Monica Graziella De Paolis. Em Busca de uma Escola - As Políticas Públicas e a Implantação do Instituto Federal de Goiás Campus Inhumas. 108fls. Dissertação de Mestrado. Universidade de Brasília ï DF ï 2011.

BLAUG, M. The methodology of economics. 2a ed. Cambridge: Cambridge University Press, 1992.

BRASIL. Boletim de desenvolvimento Fiscal- Diretoria de Estudos Regionais e UrbanosDirur. IPEA- Instituto de Pesquisa Econômica Aplicada- v. 3, Dezembro de 2006.

BRASIL. Constituição (1988). Constituição da República Federativa do Brasil. Brasília, DF. Senado Federal: Centro Gráfico, 1988. P. 292.

BRASIL. Decreto 6.301 de 12 de dezembro de 2007.

BRASIL. Expansão da Rede Federal de Educação Profissional, Científica e Tecnológica. Disponível: http://redefederal.mec.gov.br/. acessado em 18/11/2015.

BRASIL. Formação Bruta de Capital Fixo Sistema de Contas Nacionais ï Brasil -Referência 2010. Diretoria de Pesquisas ï DPE - Coordenação de Contas Nacionais ï CONAC. IBGEInstituto Brasileiro de Geografia e Estatística. Versão 2 ï Janeiro de 2015.

BRASIL. Lei 11.195 de 18 de novembro de 2005.

BRASIL. Lei 11.892 de 28 de dezembro de 2008. 
BRASIL. Lei 8.948 de 08 de dezembro de 1994.

BRASIL. Lei Federal n. 4.320, de 17 de março de 1964. Estatui Normas Gerais de Direito Financeiro para Elaboração dos Orçamentos e Balanços da União, dos Estados, dos Municípios e do Distrito Federal.

BRASIL. MEC. Centenário da Rede Federal de Educação Profissional e Tecnológica. 2009. Disponível:

http://portal.mec.gov.br/setec/arquivos/centenario/historico_educacao_profissional.pdf. acessado em 18/11/2015.

BRASIL. MEC/SEMTEC, Proposta de Políticas Públicas para a Educação Profissional e Tecnológica, dez. 2003.

BRASIL. MEC/SETEC. Plano de Expansão da Rede Federal de Educação Tecnológica ï Fase II, Brasília-DF, jan. 2007.

BRASIL. MEC/SETEC. Instituto Federal de Educação, Ciência e Tecnologia: Concepção e Diretrizes. Brasília-DF, 2008.

BRUNO, A.; LEIDECKER, J. e HARDER, J. Why Firms Fail. Business Horizons, p. 50-58. March-April/1987.

CABRAL, Caroline de Souza Rodrigues. A Evolução dos Gastos Públicos no Brasil: Por que os Gastos não param de crescer? $15^{\circ}$ SIICUSP ï Simpósio Internacional de Iniciação Cientifica. 2007.

CANDIDO Jr., J. Os Gastos Públicos no Brasil são Produtivos?. IPEA- Texto para discussão $\mathrm{n}^{\mathrm{o}} 781.2001$.

CARDOSO, André Luis Rabelo. Gestão Pública é para Gestor? Revista CRA-MG. Edição julho/15. Belo Horizonte. 2015. Acessado em Set/15. Dispinível em: http://www.cramg.org.br/gestao-publica-e-para-gestor-adm-andre-luis-rabelo-cardoso/

CARDOZO, Ricardo Magalhães Dias. Gestão Participativa na Educação Profissional-O papel do Conselho Gestor: Um estudo do Instituto Federal do Norte de Minas Geraiscampus Salinas. 2010. 150 f. Dissertação de Mestrado. Universidade de Brasília- UnB. Brasília- DF.

CHAVES, Renato Santos. A qualidade do gasto público no Brasil: propostas para melhoria. BOLETIM DE ORÇAMENTO E FINANÇAS, Curitiba: Governet, v. 3, n. 29, p. 845-855, set. 2007.

COOPER, Arnold C.; GIMENO-GASCON, F. Javier. e WOO, Carolyn Y. Initial Human and Financial Capital as Predictors of New Venture Performance. Journal of Business Venturing, v. 9, p. 371-395, 1994.

COOPER, Ronald R.; SCHINDLER, Pamela S. Métodos de pesquisa em Administração. 7 ed. Porto Alegre: Bookman, 2003. 
DANCEY. Christine P. REIDY John. Estatística sem Matemática para Psicologia. Usando SPSS para Windows. Porto Alegre: Artmed, 2006.

DELONG, J. Bradford; SUMMERS, Lawrence H. Equipment Investment and Economic Growth: How Robust Is the Nexus? Brookings Papers on Economic Activity (Fall). 1992. Disponível em: < http://delong.typepad.com/sdj/1992/08/j_bradford_delo.html>. Acessado em: 13/04/2015.

DINIZ, Eli. Em busca de um novo paradigma. A reforma do Estado no Brasil dos anos 90. São Paulo Em Perspectiva, 10(4), 1996.

FARAH, Marta Ferreira Santos. Administração pública e políticas públicas. RAP ठ Rio de Janeiro 45(3):813-36, Maio/jun. 2011.

FRANZESE, Cibele; ABRUCIO, Fernando Luiz. Federalismo e políticas públicas: uma relação de reciprocidade no tempo. 33 Encontro Anual da ANPOCS, p. 1-25, 2009.

GIL, Antonio Carlos. Gestão e Pessoas. São Paulo: Atlas, 2001.

GONZALES, Erica Oliveira; SBARDELLATI, Eliane Cristina Araújo; SANTOS, Allan Silveira dos. Uma Investigação Empírica Sobre os Determinantes do Investimento no Brasil (1995-2013). 42 ${ }^{\circ}$ Encontro Nacional de Economia. ANPEC- Associação Nacional dos Centros de Pós-Graduação em Economia. 2014. Disponível em: http://www.anpec.org.br/novosite/br/encontro-2014 . Acessado em: 06/04/2015.

GOODNOW, Frank. Politics and administration. New York: Macmillan, 1900.

GRIER, K.; TULLOCK, G. An empirical analysis of cross-national economic growth, 195180. Journal of monetary economics. 24. 259-276. 1989.

HAIR, Jr. J. F.; ANDERSON, R.E.; TATHAM, R.L.; BLACK, W. C. Análise multivariada de dados. 5. ed., Porto Alegre: Bookman, 2005.

HENRY, Nicholas. Paradigms of public administration. Public Administration Review, v. 35, n. 4, p. 378-386, 1975.

IBPT- INSTITUTO BRASILEIRO DE PLANEJAMENTO E TRIBUTAÇÃO (IBPT). Evolução da Carga Tributária Brasileira e previsão para 2013. Dezembro, 2013. Disponível em:<

www.ibpt.org.br/img/uploads/novelty/estudo/1443/20131218asscomEstudoEvolucaodacargat ributariabrasileiraPrevisaopara201 > , acessado em 20/09/2014.

IBPT. Instituto Brasileiro de Planejamento e Tributação. Carga Tributária/ PIB IDH. Org.: Gilberto Luiz do Amaral, João Eloi Olenike e Letícia Mary Fernandes do Amaral. Março/ 2014. Acessado em 13/10/2015. Disponível em: http://www.ibpt.com.br/img/uploads/novelty/estudo/1614/140403AsscomEstudo2014PIBvers usIDH.pdf 
JUNQUEIRA, Gabriel Gdalevici. Investimento Público no Brasil de 1988 a 2008: Uma analise para além da formação bruta de capital fixo. Dissertação de Mestrado. Unicamp. Campinas ï SP. 2011.

KALECKI, M. Teoria da Dinâmica Econômica Ï Ensaio sobre as mudanças cíclicas e a longo prazo da economia capitalista. São Paulo: Nova Cultural, 1990 (data do original em inglês). 1954.

KAPLAN, R.; NORTON, D. The Balanced Scorecard ï measures that drive performance. Harvard Business Review, v. 70, n. 1, p. 71-79, 1992.

KASZNAR, I. K.; GOLÇAVES, B. M. L. Regressão múltipla: uma digressão sobre seus usos. Disponível em: < http://www.ibci.com.br/Regressao_Multipla.pdf> Acesso em: 01 ago 2011.

KERLINGER, F. N. Metodologia da pesquisa em ciências sociais: um tratamento conceitual. São Paulo : EDUSP, 1980.

KEYNES, J.M. A teoria geral do emprego, do juro e da moeda. São Paulo, Editora Atlas S. A. 1982, Capítulos II ao XI, (data do original em inglês, 1936).

KLIKSBERG, B. Desigualdade na América Latina. São Paulo: Cortez, 1999.

KLIKSBERG, B. O Desafio da Exclusão. São Paulo: Edições Fundap, 1997.

LOPEZ, Julio; CARDIM, Ferdnando. Uma Estrategia de desenvolvimento na tradição Keynesiana-Estruturalista. IN: Sociedade e Economia: estratégias de crescimento e desenvolvimento. ORG: Joao Sicsú e Armando Castelar ï Brasilia: Ipea, 2009.

LUCAS, R.E.. On the Mechanics of Economic Development, forthcoming. Journal of Monetary Economics, 1988.

LUSSIER R. N. A Business Success Versus Failure Prediction Model for Services Industry. Mid-Atlantic Journal of Business, v. 32, n. 2, p. 9-92, 1996.

LUSSIER, Robert N.; PFEIFER, Sanja. A Crossnational Prediction Model for Business Success. Journal of Small Business Management, v. 39, n. 3, p. 228-239, 2001.

MACIEL, Carlos Alberto Batista. Políticas Públicas e Controle Social: encontros e desencontros da experiência brasileira. In: $\mathrm{X}$ Congresso Internacional de Humanidades. 2007. p. 24-24.

MAIA, Alexandre; VALLE, André; FROSSARD, Leila Barbiere de Matos; CAMPOS, Leila Kuhnert; MÉLO, Leonardo; CARVALHO, Marco Antônio Bastos. A importância da melhoria da qualidade do gasto público no Brasil: Propostas práticas para alcançar este objetivo. II Congresso CONSAD de Gestão Pública - Painel 32: Qualidade do gasto público II. 2009.2 Disponível em: http://www.consad.org.br/consad/acervo.aspx?menu=25728\&ttCD_CHAVE=2\&pagina=2. Acesso em 03 set. 2014. 
MAROCO, João. Análise estatística ï com utilização do SPSS. 3 ed. Lisboa (Portugal): Silabo, 2007.

MASLOW, A.H. Motivation and personality. New York: Harper \& Brothers, 1954.

MEDEIROS, Mirna de Lima. Gestores Escolares: um estudo das características e praticas presentes na gestão de escolas públicas com melhor desempenho relativo no estado de São Paulo. 2011. 235p. Dissertação de Mestrado. Apresentada à Faculdade de Administração, Economia e Contabilidade de Ribeirão Preto/ USP. Ribeirão Preto, 2011.

MERTON, Robert K. Social theory and social structure; toward the codification of theory and research. Glencoe: Free Press, 1949.

MORAES, Alexandre. Direito Constitucional. 18 ed. São Paulo: Atlas, 2005.

MOTTA, Alexandre Ribeiro. O combate ao desperdício no gasto público: uma reflexão baseada na comparação entre os sistemas de compra privado, público federal norteamericano e brasileiro. Dissertação de mestrado. Universidade Estadual de Campinas, Instituto de Economia. Campinas-SP, 2010. 189p.

MOTTA, Alexandre Ribeiro; MACIEL, Pedro Jucá; PIRES, Valdemir Aparecido. Qualidade do gasto público: revisitando o conceito em busca de uma abordagem polissêmica articulada. Textos Para Discussão 18. ESAF ï Escola de Administração Fazendária. Brasília/DF. 2014.

MOURA, Guilherme V. Multiplicadores Fiscais e Investimento em Infraestrutura. RBERevista Brasileira de Economia, Rio de Janeiro v. 69 n. 1 / p. 75 Ï 104 Jan-Mar. 2015.

MOWDAY, R. T.; STEERS, R. M.; PORTER, L. W. The measurement of organizational commitment. Journal of Vocational Behavior, v. 14, p. 224-247, 1979.

OLIVEIRA, F. A. Economia e política das finanças públicas no Brasil. São Paulo: Editora Hucitec, 2009. 325 p.

OSLAK, Oscar. Políticas públicas e regimes políticos: reflexões a partir de algumas experiências latino-americanas. Revista de Administração Pública, v. 16, n. 1, p. 17-60, jan./mar. 1982.

PEREIRA, Francisco. Possibilidades da Construção de uma Educação Emancipadora em Cursos Tecnológicos: uma abordagem a partir de dois cursos localizados em Goiânia e Anápolis. Dissertação de Mestrado. Universidade Católica de Goiás, Goiânia-GO, 2008.

PEREIRA, Luis Augusto Caldas. Institutos Federais de Educação Ciência e Tecnologia. Disponivel em Sitio oficial do MEC. Disponível em: http://portal.mec.gov.br/setec/arquivos/pdf3/artigos_ifet_jornal.pdf Acessado em 21/12/2015.

POSSAS, M. L. Demanda Efetiva, Investimento e Dinâmica: a atualidade de Kalecki para a teoria econômica. Revista Economia Contemporânea, Rio de Janeiro, v.3, p 17-46, 1999. 
RAIFUR, Léo. Fatores determinantes do desempenho de pequenas e médias empresas da região centro-sul do estado do Paraná. São Paulo, 2013. 193 p. Tese (Doutorado) ï Universidade de São Paulo.

REINHARDT, Aline Röhsler; CASTRO, Renan. Fatores motivacionais: Estudo de caso no departamento produtivo de uma empresa calçadista no Vale do Paranhana/RS. Revista de Administração de Empresas Eletrônica ï RAEE. No 1, 2015.

REIS, Cristina Froes de Borja. Os efeitos do investimento público sobre o desenvolvimento econômico: análise aplicada para a economia brasileira entre 1950 e 2006. In: Secretaria do Tesouro Nacional e ESAF. (Org.). Finanças Públicas XIII Prêmio Tesouro Nacional 2008. Brasília: Editora da UNB, 2009, v. XIII.

REZENDE, F. Avaliação do setor público na economia brasileira: estrutura funcional da despesa. IPEA/INPES. Relatório de Pesquisa n. 3, 2ª edição. Rio de Janeiro, 1974. 293p.

RIANI, Flávio. Economia do setor público. 4. ed. São Paulo: Atlas, 2002.

RIBEIRO, Márcio Bruno; JÚNIOR, Waldery Rodrigues. Eficiência do Gasto Público na América Latina. Instituto de Pesquisa Econômica Aplicada (Ipea). Boletim de Desenvolvimento Fiscal 03. Diretoria de Estudos Regionais e Urbanos ï Dirur. Dezembro de 2006.

ROCHA, Fabiana. Ajuste Fiscal, Composição do Gasto Público e crescimento econômico. IN: Gasto Público Eficiente: 91 Propostas para o Desenvolvimento do Brasil. Org.: Marcos Mendes. Instituto Fernand Braudel e Topbooks, 2006.

ROMER, P.. Endogenous Technological Change. Journal of Political Economy 98 (5), 71 ï 102. 1990.

RUA, Maria das Graças. Análise de Política Públicas: Conceitos Básicos. In: O Estudo da Política: Tópicos Selecionados, Brasília - DF: Paralelo 15, 1998.

SCHAEFER, Patricia. Why Small Business Fail: Top 7 Reasons Startups Fail and How to Avoid Failure. Disponível em: < http://www.businessknowhow.com/startup/businessfailure. htm >. Acesso em: 26/05/2015.

SEBRAE-SP. 10 anos de monitoramento da mortalidade e sobrevivência das empresas. São Paulo. 2008.

SECCHI, Leonardo. Modelos organizacionais e reformas da Administração pública. rap - Rio de Janeiro 43(2):347-69, Mar./aBr. 2009.

SELLTIZ, C. et al. Métodos de pesquisa nas relações sociais. São Paulo: Herder, 1987.

SILVA, Glenio Luiz da Rosa. Controle do turnover: como prevenir e demitir com responsabilidade. Rio de Janeiro: Qualitymark, 2001. 
SILVA, Romildo Araújo da. Evolução e Dinâmica dos Gastos do governo Federal Brasileiro no período 1995-2005. Universidade de Brasília, Universidade Federal da Paraíba, Universidade Federal de Pernambuco e Universidade Federal do Rio Grande do Norte Brasília. 2007.

SIMON, Herbert A. Administrative behavior: a study of decision-making processes in administrative organization. New York: Macmillan, 1947.

TEIXEIRA, Erly Cardoso; RODRIGUES, Rodrigo vilela. Gasto Público e Crescimento Econômico no Brasil: uma analise comparativa dos gastos das esferas de Governo. RBE. Rio de Janeiro. V.64. n 4/p 423 ï 438. Out, 2010.

VAN PRAAG, C. Mirjam. Business Survival and Success of Young Small Business Owners. Small Business Economics, v. 21, n. 1, p. 1-17. Aug./2003.

VELlOSO, Raul; MENDES, Marcos; CAETANO, Marcelo. Saindo da Crise, a Política Fiscal e os Investimentos. XXII Fórum Nacional - Na Crise, Brasil, Desenvolvimento de uma Sociedade Ativa e Moderna, 2009.

WALDO, Dwight. The administrative state: a study of the political theory of American public administration. New York: Ronald Press 1948.

WALTENBERG, F. D. Teorias econômicas de oferta de educação: evolução histórica, Estado atual e perspectivas. Educação e Pesquisa, São Paulo, v.32, n.1, p.117-136, jan-abr. 2006.

WILSON, Woodrow. The study of administration. Political Science Quarterly, v. 2, June 1887 [reproduzido no v. 56, Dec. 1941].

WOOD, S. J. Getting the measure of the transformed high-performance organization. British Journal of Industrial Relations, 37(3), 391-417. 1999. 


\section{APÊNDICE A: Texto de apresentação do Questionário}

UNIVERSIDADE DE BRASÍLIA - UnB
CÂMPUS PLANALTINA
PROGRAMA DE PÓS GRADUAÇÃO EM GESTÃO PÚBLICA
Caro Diretor/Coordenador!
Este questionário tem por objetivo a construção de uma base de dados para a Dissertação
de Mestrado, cujo tema é ñFatores Determinantes da Qualidade do Gasto Público na Educaçãoò.
Encarecidamente pedimos não mais do que 5 minutos do seu precioso tempo, pois
dependemos da colaboração dos Senhores para que os objetivos da pesquisa sejam alcançados.
Ademais, acresce-se que o próprio questionário poderá ser uma forma de auto-reflexão
sobre a gestão realizada em seu campus.
Asseguramos o sigilo e o anonimato das informações aqui prestadas.
Desde já agradecemos a sua valiosa colaboração!

André Luís Rabelo Cardoso

Diretor de Administração do IFNMG

Mestrando em Gestão Pública UnB

Tel: (38) 3629-4624/9115-3266 


\section{APÊNDICE B: Questionário}

\section{Capital Humano}

1.1. Antes de ser Diretor(a)/ Coordenador(a), você já havia trabalhado em empresas privadas como empregado?
Não
Menos de 1 ano
$\bigcirc$ De 1 a 5 anos
De 6 a 10 anos
$\bigcirc$ De 11 a 20 anos
Mais de 20 anos

1.2. Antes de ser Diretor(a)/Coordenador(a), você ocupou cargo/função na qual possuía pessoas/empregados sob seu comando?
Não
Menos de 1 ano
De 1 a 2 anos
De 3 a 5 anos
De 6 a 10 anos
Mais de 10 anos

1.3. Há quantos anos você está no cargo em que ocupa nesse campus:
5 anos ou menos
6 a 10 anos
11 a 20 anos
21 a 30 anos
acima de 30 anos

1.4. Escolaridade (nível completo):
Ensino Médio
$\bigcirc$ Ensino Superior
Especialização
Mestrado
Doutorado 


\section{Capital Social}

2.1. Com relação aos principais fornecedores de materiais e serviços da Instituição, como você avalia a contribuição deles ao desenvolvimento do campus:
$\bigcirc$ Muito pouco $\bigcirc$ pouco
Orazoável
$\bigcirc$ bom
Muito bom

2.2. Vocês utilizaram outros serviços especializados, como consultorias externas, para determinar ou melhorar o desempenho da sua unidade?

$$
\bigcirc \operatorname{Sim} \bigcirc \text { Não }
$$

2.3. Em geral, como você avalia o suporte governamental dado a sua instituição:
$\bigcirc$ Muito pouco $\bigcirc$ pouco
razoável
$\bigcirc$ bom
Muito bom

2.4. Em geral, como você avalia o suporte da sua Reitoria dado ao seu campus:
$\bigcirc$ Muito pouco $\bigcirc$ pouco
razoável
$\bigcirc$ bom
Muito bom

\section{Características Gerenciais}

3.1. Existe interferência ou ingerências de ações políticas sobre ações técnicas?
$\bigcirc$ Muito pouco $\bigcirc$ pouco
Oregular
muito
totalmente

3.2. Qual o grau de planejamento sobre as compras e gastos realizados no campus?
$\bigcirc$ Muito pouco $\bigcirc$ pouco
regular
muito
totalmente

3.3. Como você considera o grau de rigidez operacional, em decorrência da burocracia, inerente ao serviço público, no seu campus?
$\bigcirc$ Muito pouco $\bigcirc$ pouco
regular
muito
totalmente

3.4. A empresa reconhece os bons funcionários?
Muito pouco $\bigcirc$ pouco
Oregular
muito
totalmente 


\section{Motivação e Cultura}

4.1. No geral, como você julga o grau de motivação ao trabalho de sua equipe?
Muito pouco $\bigcirc$ pouco
regular
muito
totalmente

4.2. Vocês possuem servidores pouco motivados, com hábitos de sabotagem operacional na sua equipe?
Muito pouco $\bigcirc$ pouco
regular
muito
totalmente

4.3. Você acha que a busca por uma função comissionada impulsiona a ação dos servidores colaboradores?
$\bigcirc$ Muito pouco $\bigcirc$ pouco
regular
muito
totalmente

4.4. A sua equipe costuma trabalhar além do horário de serviço, ou, caso necessário, nas férias?
Muito pouco
pouco
regular
muito
totalmente

\section{Percepção de Desempenho}

5.1. Se fosse para ranquear o grau de desperdício que vocês possuem no campus, como você o avaliaria?
Muito pouco $\bigcirc$ pouco
regular
muito
completamente

5.2. Vocês consideram que o aumento da quantidade de recurso em investimento é resultado do uso eficiente dos recursos destinados ao custeio da instituição?

$$
\begin{aligned}
& \text { sim } \\
& \text { não }
\end{aligned}
$$

5.3. Em termos macroeconômicos, você acredita que o gasto em investimento é mais produtivo que o gasto em custeio?

$$
\begin{aligned}
& \text { sim } \\
& \text { não }
\end{aligned}
$$

5.4. Você considera o campus em que está uma máquina enxuta? Sem gastos desnecessários?
Muito pouco $\bigcirc$ pouco
Oregular
$\bigcirc$ muito
completamente 


\section{Características Organizacionais}

6.1. Em geral, o quadro de servidores envolvidos na gestão dos recursos financeiros/orçamentários do seu campus pode ser definido como:

$\bigcirc$ Muito qualificado $\bigcirc$ Pouco qualificado $\bigcirc$ Qualificado $\bigcirc$ Sem qualificação

6.2. No geral, o quadro de servidores envolvidos na gestão dos recursos financeiros/orçamentários possui experiência profissional na área privada?

Muito qualificado $\bigcirc$ Pouco qualificado $\bigcirc$ Qualificado $\bigcirc$ Sem qualificação

6.3. Por ano, em média, quantas horas de treinamento (cursos, palestras, feiras etc.) estes servidores realizam, individualmente?

$\begin{array}{ll}\bigcirc \text { Menos de } 12 \text { horas por ano } & \bigcirc \text { De } 12 \text { a } 24 \text { horas } \\ \text { De 25 a } 48 \text { horas } & \bigcirc \text { Mais de } 48 \text { horas }\end{array}$

6.4. Qual o grau de sinergia compartilhado entre os seus Diretores/Coordenadores:
$\bigcirc$ Excelente $\bigcirc$ Bom
$\bigcirc$ Regular
Ruim
Péssimo 


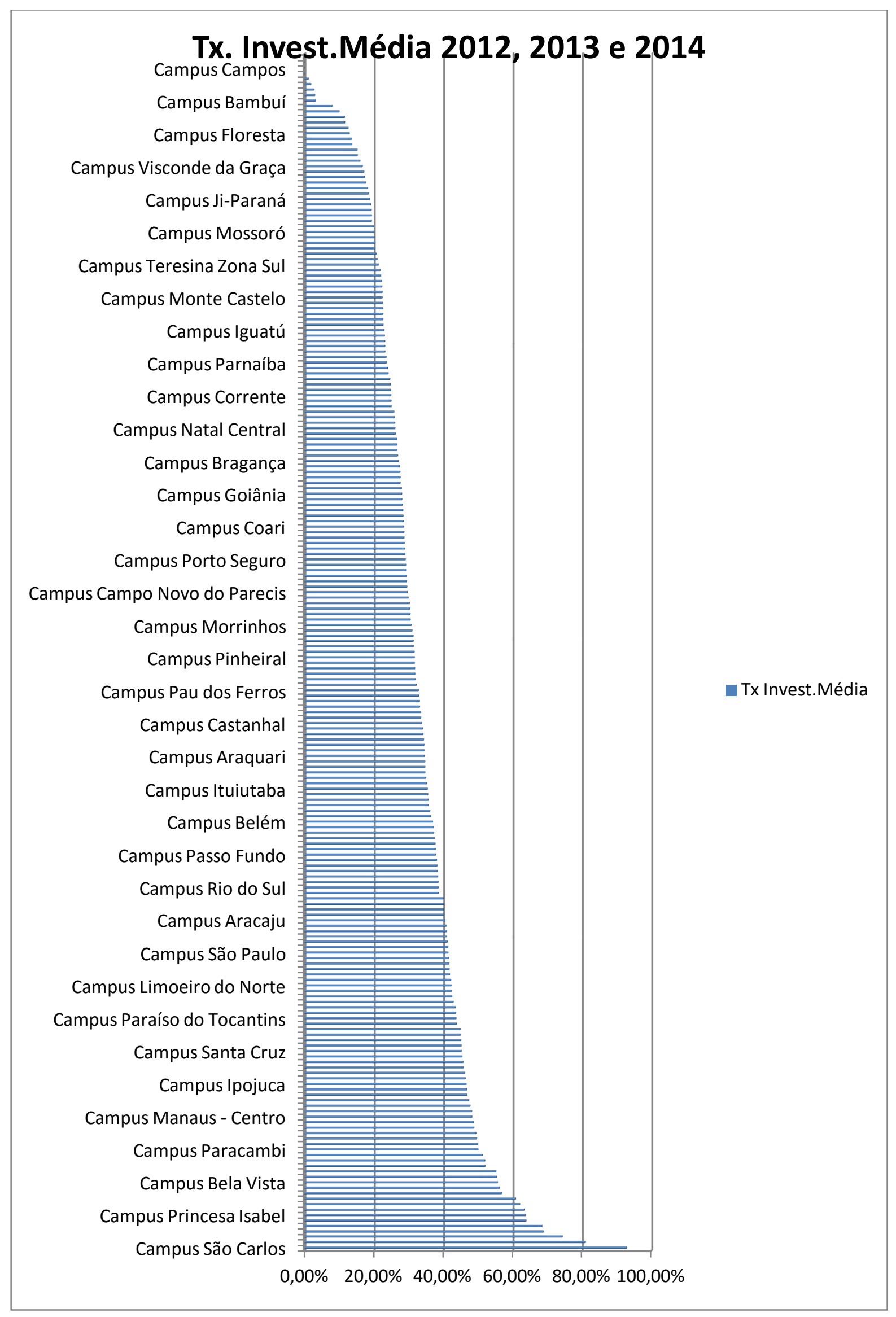

